\title{
$\gg \mathrm{K}$ nam so prišli Francozi in prinesli ,drugačne čase“ «: Napoleonovi Francozi $\mathrm{v}$ slovenskih povedkah $\mathrm{v}$ kontekstu kolektivnega spomina in drugosti
}

\begin{abstract}
Anja Mlakar
This paper attempts to shed light on the image of Napoleon's French forces that invaded and briefly conquered Slovene lands in the late $18^{\text {th }}$ and early $19^{\text {th }}$ centuries, as depicted in Slovene folklore. In some legends, we can recognize an echo of the historical reality of the time of French invasions and their rule. These portray the hardships of this foreign occupation, the exploitation of the population by the French and their cruelty and conflicts with them, yet some show a more favourable relationship or even depict humorous accounts (especially in relation with linguistic misunderstandings) with the French, while some aspects of their rule are completely ignored by folklore. In some cases, the French are narrated into stories that explain certain features of the physical environment of the community, and in some legends they are depicted as coming from the world beyond and are attributed supernatural traits. In some folklore examples, the interchangeability of different historical invaders is attested. We can generalize that the French are seen as "the Others" in Slovene folklore and have, as such, acquired different roles in folklore to serve diverse needs of the community in the sense of strengthening its own identity, rationalizing its physical landscape, and taking part in the beliefs about the supernatural and the world beyond.

KEYWORDS: Napoleon's French forces, Slovene folklore, collective memory, otherness, history vs. folklore, materialization of folklore
\end{abstract}

Slovstvena folklora pogosto obravnava dogodke iz zgodovine, pri čemer prihaja do kompleksnega prepletanja med zgodovinskimi dejstvi in percepcijo skupnosti o svoji lastni preteklosti, ki se odraža tudi v obliki slovstvene folklore. Ta sicer črpa svojo vsebino iz zgodovinskih obdobij in dogodkov, ki jih skupnost dojema kot pomembne, a podrobnejši pregled pokaže celo vrsto historičnih nedoslednosti, ki jih lahko razložimo, če poznamo načine, kako folklora odgovarja na različne potrebe skupnosti. V slovenski slovstveni folklori so velik vtis pustili zgodovinski osvajalci slovenskega ozemlja, predvsem Turki in v manjši meri Francozi, ki so tema tega prispevka. »Francoska doba« je na Slovenskem sicer trajala zgolj štiri leta, ${ }^{1}$ a je v zgodovini pustila velik pečat. To obdobje je predstavljalo

\footnotetext{
1 Francozi so na Slovensko prvič prišli leta 1797, ko so pod Napoleonovim vodstvom premagali Avstrijce v severni Italiji. Del francoskih čet je takrat zasedel velik del slovenskega ozemlja. Francoski poveljniki so
} 
posebnost že v tem, da je del slovenskih dežel po več stoletjih izšel iz habsburškega okvira (Polajnar 2009: 27-28). Ljudske povedke se pogosto nanašajo na dramatične dogodke v narodovi zgodovini (Brunvand 1968: 99) in med takšne lahko štejemo tudi povedke, ki govorijo o času Napoleonovega osvajanja slovenskih dežel. Splošne značilnosti povedke kot žanra so, da gre načeloma za enoepizodne, visoko ekotipizirane, lokalizirane in historizirane zgodbe, v katerih resničnost se verjame ${ }^{2}$ (Tangherlini 1994: 22). Hkrati pa Francoze obravnavam kot Druge, torej kot skozi proces drugačenja konstruirano navidezno homogeno skupnost, preko katere se definira Naša skupnost. Identiteta in drugost sta namreč nerazdružljivo povezani, saj svojo identiteto ustvarimo v odnosu do drugih. Pri tem gredo etnocentrične ${ }^{3}$ konstrukcije Drugega vedno skozi proces, v katerem je drugost zreducirana na tisto, kar je poznano in razumljivo Jazu skupnosti. Etnocentrične so tiste povedke, ki govorijo o tujcih in pripadnikih drugih etničnih skupnosti ter pri tem odražajo vrednote lastne skupnosti (Klintberg 1989: 72-73). Drugost, ki se v folklori pojavlja opredeljena z zgodovinskimi imeni in je umeščena v določeno zgodovinsko obdobje (koliko se pri tem naslanja na resnično zgodovinsko dogajanje, ni bistveno),

poskušali prestrašene prebivalce (ki so bili pod vtisom avstrijske protifrancoske propagande) pomiriti s posebnimi razglasi, hkrati pa so obljubljali spoštovanje vere, lastnine in običajev. Na slovenskih tleh so ostali le dobra dva meseca in se po premirju v Leobnu začeli umikati (Vodopivec 2006: 22).

Drugič so Francozi slovensko ozemlje zasedli med tretjo koalicijsko vojno leta 1805. Tokrat do prebivalcev niso bili tako popustljivi in so nanje v celoti preložili breme vojaške oskrbe, uvedli visoke davke in jemali talce. Tudi ta zasedba je trajala slaba dva meseca in je prebivalstvu ostala v precej slabšem spominu (Granda 2006: 293; Vodopivec 2006: 23).

Tretjič je francoska vojska slovensko ozemlje zasedla leta 1809. Poleg avstrijske propagande so odklonilno razpoloženje do francoskih gospodarjev še povečali njihovi ukrepi, ki so vključevali občutno večje dajatve in prispevke kot v času druge zasedbe, pa tudi njihova oblast je bila nasilnejša. Prihajalo je do kmečkih uporov (največ na Dolenjskem in Notranjskem), saj se je finančni pritisk na kmete še povečal, in do spopadov med francoskimi vojaki in brambovci, kar je še zaostrilo francoski pritisk. Razmere so se umirile šele po ustanovitvi Ilirskih provinc (te so poleg dežel, ki jih je Francozom morala odstopiti Avstrija - Kranjske, Primorja, zahodne Koroške in Hrvaške na desnem bregu Save - obsegale še ozemlje beneške Istre, Dalmacije in Boke Kotorske ter Dubrovniške republike, leta 1810 so jim priključili še vzhodno Tirolsko z Lienzom, hkrati pa so v Posočju preuredili mejo z Italijo (Vidic 2001: 204)) oktobra 1809 po podpisu miru v Schönbrunnu (Vodopivec 2006: 23; tudi Granda 2006: 293). Province so obsegale 55 tisoč $\mathrm{km}^{2}$ in imele okoli milijon in pol prebivalcev (Slovencev, Hrvatov, Srbov, Nemcev in Italijanov); glavno mesto je bila Ljubljana. Obstajale so le dobra tri leta in pol, do 1813 (Vidic 2001: 204; Vodopivec 2006: 23-26).

V Ilirskih provincah so veljali francoski zakoni, vendar ne vsi. Francozi so uvedli splošno vojaško obveznost za vse državljane in enakost pred zakonom, odpravili davčne privilegije in poenotili davčni sistem, ukinili patrimonialna sodišča ter zemljiškim gospodom odvzeli javnopravne funkcije, podržavili so sodstvo, vpeljali moderno uradniško upravo in modernizirali šolstvo. Medtem ko mnogi ukrepi v kratkem času francoske oblasti še niso prinesli pozitivnih rezultatov, pa so hitro prišli do izraza negativni učinki nekaterih izmed njih (Vodopivec 2006: 25; Polajnar 2009: 28).

2 Verjetje (angl. belief) je sicer v folkloristiki problematičen têrmin. O tem je pisal Kvartič (2014: 103-104). Verjetje je sicer del vsake povedke, ki ga kontekstualizira in interpretira (Dégh 1996: 34). V preteklosti so folkloristi svoje raziskave utemeljevali na predpostavki, da v povedkah sicer ni mogoče najti objektivne resnice, da pa pripovedovalec in občinstvo verjamejo v njihovo resničnost. A kot se je izkazalo, verjetje pripovedovalca in poslušalcev ni nujno potrebno za širjenje povedke (Dégh, Vászonyi 1976), saj verjetje ni konsistentno in absolutno, ampak selektivno in spreminjajoče se (Dégh 1996: 39).

3 Pri etnocentrizmu gre za sistem predstav o lastni skupnosti, ki so ji večinoma pripisane pozitivne lastnosti, $v$ odnosu do skupnosti Drugih, ki so jim večinoma pripisane negativne oznake. Torej gre za vrednotenje drugih skupnosti z vrednostnim sistemom lastne skupnosti, pri čemer je to, kar je Naše, označeno kot »normalno«, »pravilno«, nasprotno pa je to, kar pripada Drugim, označeno kot odstopanje od norm, kot »nenormalno«, »napačno« (Leerssen 2007: 323-324; tudi Anglickienè 2004: 83). 
lahko dojemamo kot del kolektivnega spomina skupnosti. ${ }^{4}$ Kolektivni spomin je del kulturnega aparata, ki ustvarja smisel. V njem se iščejo razlage za aktualne probleme, prav tako primerjave s preteklostjo dajejo spominu moč vplivati na sedanjost. Spomin se lahko dojema kot simbolični okvir za pojmovanje sveta, hkrati pa ima pomembno vlogo pri ustvarjanju osebnih in kolektivnih identitet (Kuljić 2012: 28).

Med zbranim folklornim gradivom o Francozih je največ etioloških in zgodovinskih povedk. Med prve sicer spadajo zgodbe o stvarjenju sveta, o izvoru stvari, o izvoru nenavadnih naravnih pojavov in geoloških formacij ter lastnosti rastlin in živali (Dégh 1982: 76). Zgodovinske povedke pa so del naracije, izhajajoče iz zgodovine skupnosti. Temeljijo na spominih na pretekle dogodke, hkrati pa tudi na pisnih virih v obliki šolskih učbenikov, medijev ipd. Najpogostejši vrsti zgodovinskih povedk govorita o narodnih in družbenih junakih (tj. o pravičnih vladarjih in odpadnikih) ter o dogodkih, ki so vplivali na življenje skupnosti, kot so napadi sovražnikov, krutosti vladarjev, epidemije ipd. Druge (tu se zgodovinske povedke precej povezujejo z etiološkimi - op. A. M.) govorijo o imenih krajev, rek, o izvorih prazgodovinskih ruševin in gomil (Dégh 1982: 76), dejansko pa imajo z zgodovino skupno le to, da jim ta daje časovni okvir ali posoja resnične zgodovinske osebnosti. Navadno se niti pripovedovalec niti poslušalec ne menita veliko za zgodovinsko resničnost $\mathrm{v}$ zgodbi - pomembno je predvsem to, da vzbuja videz resničnosti. Tako je tudi dogodek, ki ga povedka tesno povezuje s konkretnim krajem ali zgodovinsko osebnostjo, mogoče večkrat srečati v krajih, ki so med seboj oddaljeni, ali pa je pripisan različnim zgodovinskim osebam (Stanonik 1999: 285). Kljub zgodovinskim nekonsistentnostim pa je treba folkloro z zgodovinsko tematiko preučevati v kontekstu zgodovinskega obdobja, na katero se nanašajo, saj lahko le na ta način - tj. preko primerjanja folklore z zgodovinskimi dejstvi - pridemo do odgovorov na vprašanja, kako to obdobje odmeva v kolektivnem spominu oz. v kolikšni meri se historična realnost meša $\mathrm{s}$ folklornimi predstavami in na kakšne potrebe skupnosti ta folklora odgovarja. Zato so obravnavane povedke tematsko razdeljene $\mathrm{v}$ različne kategorije (sicer precej ohlapno zamejene, ker je folklora o Francozih precej raznolika). Niso navedeni vsi primeri, ampak zgolj nekaj povedk, za katere se mi je zdelo, da so tipične za vsebinsko kategorijo, v katero sem jo umestila. ${ }^{5}$ Znotraj teh kategorij je vsebina obravnavanih pripovedi kon-

\footnotetext{
4 Pri tem izhajam predvsem iz Halbwachsovega koncepta kolektivnega spomina in se ne poglabljam v kritike le-tega, kot je npr. ta, da Halbwachs ne upošteva dinamike osebnega spomina, ki je lahko drugačna od dinamike kolektivnega spomina, ter da s tem posameznika pretvarja v pasivni objekt kolektivne zavesti, ali pa kritika hermenevtike, za katero je kolektivni spomin preveč abstraktna posplošitev, ki spomin razume kot nekakšen spomenik. Hermenevtiki poudarjajo, da obstajajo le kolektivni pogoji možnega spominjanja (npr. politični, religijski); ti z vidika osebnih izkustev vsakega posameznika oblikujejo različne spomine. Halbwachs podobo preteklosti v kolektivnem spominu dojema kot nekaj stabilnega, zato na podobno statičen način dojema tudi identitete. Zanimiv je tudi pristop, ki ga je razvil Pierre Nora. Ta trdi, da spomin, ki ga ima skupnost, ni odraz njene »kolektivne duše«, ampak je produkt družbe, razširjan z mediji, institucijami, simboli in znaki, pri čemer imajo pomembno vlogo kraji spomina (fr. lieux de mémoire) kot točke kristalizacije kolektivnega spomina in identitete, kot so arhivi, muzeji, spomeniki, ki odmerjajo prisotnost preteklosti v sedanjosti (Kuljić 2012: 107-111). Kako bi se tovrstne kritike aplicirale na kolektivni spomin znotraj slovstvene folklore, bi bila tema druge raziskave, zato se na tej točki v to ne bom poglabljala.

5 V raziskavi nisem upoštevala nekaterih povedk, v katerih so Francozi zgolj omenjeni oz. dajejo časovni okvir zgodbi, nimajo pa zveze s samo vsebino povedke oz. ta ne pove ničesar o njih samih. Primer: »K nam v Podgrad je za cajta još prvog, morda je blo tu za cajta Napoleona, Rika-Trst je bla ciésta, aš je bla puóšta.
} 
tekstualizirana v skladu z zgodovinskimi podatki, procesi konstrukcije (zgodovinske) drugosti v folklori in kolektivnem spominu in njene materializacije v (fizični) krajini ter tradicijskimi predstavami v folklori, ki se ne ozirajo na empirično in historično točnost - vse to se namreč da izluščiti iz teh na prvi pogled preprostih pripovedi. Boris Kuhar, ki je folkloro o Francozih vsebinsko razdelal že leta $1964,{ }^{6}$ je sicer mnenja, da so bile (v času pisanja njegovega članka - op. A. M.) mnoge folklorne pripovedi še zelo natančne, saj je v njih mogoče najti imena kmetov in krajev, ki so takrat še obstajali, so pa hkrati povedke večkrat pomešane »z raznimi podobnostmi iz drugih zgodovinskih obdobij« (Kuhar 1964: 100). O spajanju različnih zgodovinskih obdobij v folklori o Francozih bo sicer govor nekoliko kasneje.

\section{KAJ SE UJEMA Z ZGODOVINSKIMI DEJSTVI?}

Če na slovensko folkloro o Francozih najprej pogledamo z vidika njenega ujemanja z zgodovinskimi podatki, ${ }^{7}$ se pokaže, da v njenem pomembnem delu odzvanja kolektivni spomin na boje z njimi in francosko zasedbo slovenskih dežel. To seveda ne pomeni, da prikazuje zgodovinsko resničnost kot takšno, odraža pa posplošen spomin na ta čas, četudi z določenimi domišljijskimi elementi. Hkrati pa izpostavlja zgolj določene vidike iz tega zgodovinskega obdobja: v pripovedih tako ne najdemo ničesar o npr. ideološko-političnem konceptu Ilirskih provinc - to je bila domena izobražencev (npr. Valentina Vodnika), v folklori se odražajo predvsem vsakodnevne težave francoske okupacije in dojemanje Francozov kot okupatorjev. Ko se je v 50. letih prejšnjega stoletja Zmaga Kumer (1957) lotila primerjanja slovenske ljudske pesmi, ki omenja Francoze (in to predvsem na podlagi Štrekljeve zbirke (Slovenske narodne pesmi $=$ SNP I-IV) ${ }^{8}$ ), z znanimi zgodovinskimi podatki in poskušala vsebino pesmi povezati s konkretnim zgodovinskim dogodkom iz

\footnotetext{
To je - kočije su vozili.«(Pugelj 2012: 302)»V prejšnjih časih so hodile ksv. Andreju procesije, ko pa so prišli Francozi, se je to pozabilo.« (Kotnik 1957: 46) Je pa tudi res, da je ta zadnji primer morda odraz cerkvenih reform, ki so jih uvedli Francozi in s katerimi so med drugim odpravili več zapovedanih praznikov ter razne pobožne navade, kot so procesije (Gruden 1911: 19). Vse povedke, ki sem jih za raziskavo zbrala in raziskala, so navedene v nalogi Drugi v slovenski folklori (Mlakar 2016).

6 Gre za članek Francozi v slovenskem ljudskem izročilu (1964). Povedke je Kuhar (1964: 99), poleg zbiranja na terenu, našel tudi v besedilih Josipa Grudna Spomini na Francoze in Josipa Mala Zgodovina slovenskega naroda, mnogo izročil pa je bilo, kot pravi, raztresenih po različnih revijah in časnikih (Ljubljanski zvon, Letopis Matice Slovenske, Novice, Vrtec, Etnolog, Slovenski narod, Laibacher Schulzeitung idr.), v šolskih in župnijskih kronikah, nekaj gradiva hranijo v arhivu Inštituta za slovensko narodopisje pri SAZU in v arhivu Slovenskega etnografskega muzeja. Folkloro poskuša deloma tudi umestiti v zgodovinski okvir in jo geografsko locirati, dotakne pa se tudi tega, kako se je to izročilo materializiralo v pokrajini (npr. ledinska imena, materialni ostanki) in ljudski umetnosti. Krajši vsebinski pregled folklornih pripovedi o Francozih na Slovenskem pa je naredila tudi Mojca Ferle (2009), pri čemer se ni spuščala v interpretacijo, ampak je predstavila zgolj njihovo vsebino.

7 Iskanje zgodovinske osnove povedk in preverjanje njihove vrednosti v arheoloških in zgodovinskih raziskavah je bilo težnja pri raziskovanju ob koncu 19. ter v začetku 20. st. in šele v 70. letih 20. st. je bilo vprašanje zgodovinskosti povedk postavljeno pod vprašaj (gl. Tangherlini 1990: 378).

${ }_{8}$ Za pesem Francozi v Ljubljani poleg verzij v SNP navaja tudi inačice v zbirki Odbora za nabiranje slovenskih narodnih pesmi in Kokošarjevi zbirki (Glasbenonarodopisni inštitut v Ljubljani) (Kumer 1957: 18).
} 
»francoskih časov«, ji je to uspelo v več primerih ${ }^{9}$. Nemirni časi francoske navzočnosti so po njenem mnenju v naših krajih pri ljudeh pustili tako močan vtis, da so bile ne samo ustvarjene nove pesmi s to tematiko, pač pa se je ime Francozov začelo pojavljati tudi v številnih starejših vojaških pesmih. ${ }^{10}$ Pesmi po njenem odsevajo razmere in dogajanje v času francoske okupacije (Kumer 1957: 17).

Tudi mnoge povedke odsevajo splošno klimo v tistem obdobju. Časi francoske zasedbe slovenskih dežel so bili za prebivalce težki zaradi velikih bremen, ki sta jih naložili francoska vojska in uprava. V skladu s francosko politiko so namreč morali za potrebe vojske poskrbeti prebivalci zasedenega območja (za podrobnosti o tem prim. Kolar 2012). Vojno stanje je bilo težko že samo po sebi, tudi obnašanje vojakov ni bilo pretirano drugačno kot v kateri koli drugi vojni - materialna izkoriščanja in plenjenja so bila kljub prepovedim običajna (Granda 2006: 294).

»Uoni so imajlə velike struoške, tud dauk so bl zelu velikə. Pualaj k-so Austricə nezaj pəršlə, so use zakuone ukinlə, samu dauku ne!« (Ožbolt 2004: 118-119, št. 254)

»Ko so Francozi prišli k nam, so dejali, da bodo naredili red. Odpravili so desetino, naložili pa so davke, ki so jih ljudje imenovali fronke. Še pôl pod Avstrijo so rekli davkom le fronki. Oča je dejal:

,Bom šel v Loko, bom plačal fronke.' « (Dolenc 2000: 85, št. 249)

»Kot vsaka armada je tudi francoska jemala kmetom živino za prehrano vojaštva in druge potrebe. Poleg tega bremena so posamezni vojaki in skupine šle kar na svojo roko po hišah z izgovorom, da iščejo skrite sovražne vojake, preiskovat in ravbat in iz hiš so odnesli vse, kar je bilo kaj vrednega in njim všeč. Tako so pripovedovali, da je tedanja Luksana sama vse po hiši razmetala, posteljnino, omare in skrinje, v hiši in v kamrah, sploh, koder je bilo kaj takega, da bi vojake privlačilo, potem pa je sedla pred hišo na klop in vekala. Ko so to videli vojaki, so mislili, da so že pred njimi drugi vojaki preiskali hišo in naredili razdejanje[,] in se nobena skupina ni ustavila in ravbala Luksove hiše. Nekdo iz patrole je celo listek napisal in ga stavil na vežna vrata, na katerega je napisal, da ne sme nobeden te hiše preiskovati, ker je že preiskana. Tako je njena domiselna zvijača obvarovala, da ji ni bila hiša poravbana.« (Zupan 1999: 69, št. 97)

V kolektivnem spominu so se ohranile davčne dolžnosti v času francoske okupacije. Francozi so od prebivalcev zahtevali zelo visoke izredne davke, ogromno opreme za vojsko

\footnotetext{
9 Npr. pesem Vrh Ljubelja šance stavil (SNP IV/7177) se nanaša na francosko-avstrijske boje za ljubeljski prelaz leta 1813 (Kumer 1957: 18).

${ }^{10}$ Eden od primerov, ki jih v zvezi s tem navaja, je pesem Čudno se ti bo zdelo, ko pridem v suknji beli (SNP IV/6937), katere vsebina kaže na večjo starost (npr. »glavico poštupano«, tj. popudrano, kar je bilo značilno za vojake v 18. st.) (Kumer 1957: 17).
} 
v raznovrstnem perilu in obutvi ter živino, naložili so jim tudi veliko dela, povezanega s premiki vojaštva. Prebivalci so med vojno morali tudi vzdrževati francosko armado, v času Ilirskih provinc pa so vse finančno breme francoskih ukrepov morale nositi province same, kar je pomenilo visoka davčna bremena. To pa je seveda še krepilo protifrancosko razpoloženje ter ostalo na Slovenskem v slabem spominu (»fronki«) še dolgo po koncu provinc. Izvajali so tudi razna prisilna posojila ipd. Veliko stvari so morali izterjati prisilno, kar je pomenilo, da so v vas ali h kmetu naselili določeno število vojakov, ki jih je bilo treba prehranjevati in jim izplačevati dnevnice toliko časa, dokler ni bil dolg poplačan (Vodopivec 2006: 25; Granda 2009: 208-210). Te dolžnosti, obveze in upravni ukrepi, ki so se izvajali pod Francozi, so glede na številčnost omemb v povedkah v kolektivnem spominu pustili močan vtis. V negativni luči se odraža tudi spomin na konskripcije mladih fantov za vojsko. Francozi so namreč uvedli splošno vojaško obveznost in izvajali novačenja, ki so se jim mnogi fantje želeli izogniti (Granda 2009: 211; gl. tudi Šumrada 2010: 30; prim. še Kure 2004: 79, št. 157).

»Pred več ko 120 leti so v Savinjski dolini pričakovali Napoleonove Francoze. Zaloški graščak je učil kmete, kako se jim je treba postaviti po robu. Vsak kmet si je moral doma narediti sulico in hoditi h graščakovim vojaškim vajam. Nekateri ga sicer niso poslušali.

Ko pa so prišli Francozi, z odporom ni bilo nič. Kmetje se niso zbrali in nihče jih ni klical. Pač pa so gledali, da pred Francozi čim prej zbeže. Pa to se jim ni vedno posrečilo.

Bilo je v Rušah, majhnem naselju pri Zalogu. Izmed zakasnelih kmetov je eden v naglici prevrgel omaro in se skril vanjo, drugi je pa nalagal slanino. Tega so Francozi zgrabili in ga odvedli s seboj v Zalog. Tam je graščak Francoze silno prijazno sprejel in kmet se kar ni mogel načuditi razliki med prejšnjo njegovo bojevitostjo in sedanjo prijaznostjo. Uporabil je pa ugodno priliko ob sprejemu in je pobegnil.« (Orožen 1936: 61)

Za zadnjo povedko lahko rečemo, da se sklada z zgodovinsko realnostjo: ob prvem prihodu v slovenske dežele je namreč francoska vojska prebivalstvo mirila $\mathrm{z}$ razglasi $\mathrm{v}$ slovenščini, medtem ko ob svojem drugem prihodu leta 1805 do lokalnega prebivalstva niso več pokazali takšnega razumevanja. Zato so bili leta 1809 Francozi sprejeti s precejšnjim strahom in odporom, $\mathrm{k}$ čemur sta prispevala tudi dodatna protifrancoska propaganda ter spodbujanje avstrijskega in deželnega domoljubja (Polajnar 2009: 27). Avstrijska oblast se je namreč želela na vojne s Francozi bolje pripraviti. Med drugim so poleg vojske organizirali tudi deželno brambo, ki je bila bolj odvisna od lokalne oblasti. Običajno so ji poveljevali lokalni plemiči z vojaškimi izkušnjami. A vojaške reforme so se izkazale za nezadostne, brambovci niso odigrali predvidene vloge in načrtovani širši upor proti francoski zasedbi ob prihodu Francozov ni uspel (Granda 2006: 209).

Več povedk se nanaša tudi na upravne ukrepe, ki so jih Francozi izvajali, ko so dobili oblast nad osvojenim ozemljem. Omenjajo strožji pravni red, ki ga je uvedel 
Napoleon, in kazni za prekrške, ki so jih izvajali. To je spomin na resnične uredbe pod francosko upravo, katerih rezultat je bil, da so se varnostne razmere na podeželju, zlasti pa v prometu, zelo izboljšale, saj so se nezakonitosti ostro preganjale. Upadlo je tudi število cestnih ropov, povečala se je varnost v naseljih (Granda 2009: 211). Ničesar pa ni npr. rečenega o drugih vrstah reform, ki so jih izvedli Francozi, kot so bile npr. odprava plemstva, ločitev sodstva od uprave, nova lokalna uprava, verske reforme (Granda 2006: 210-211) - najbrž zato, ker so trajale tako kratek čas, da niso imele priložnosti pustiti sledi v kolektivnem spominu.

»Tukaj, ki so Francuózi šli, se je kralu. Tukaj so šli z vozovi, puóšta je hodila tukaj, je bəla Marija Teriêzija, ki je nardila to cejsto tukaj, pa čez Škavnico, tu je bəla stara cesta. Pa tákrat so se velike kradnje pojavile. Puôl je Napoleon, ki je pəršu, uôn je bil táku bolj strog, 'du je kaj ukral, ga je obejsil. Pa so riêkli [nerazumljivo], tam zduôla cejstə riêčejo Gavge. Te gavge, tisti, ki je kaj ukral, so ga pa obejsili, táku da se je kradnja puôlje bolj [nerazumljivo], zatu se riêče še dənəs ena particéla Gavge, kəmər jih je uôn obejsil, dal obejsit, niê.« (Pugelj 2012: 299, št. 559)

Značilen je tudi motiv obveznega sajenja hrušk, ki naj bi ga ukazali Francozi.

»So muoglə pod Napoleona usaka hiša dva dərviesa usadət. Tistu so pa muoglə. Napoleon je duastə dau ne hrano, hrano obdržat. Suhe hruške so pa le ble, druzga naj blu. Osenice so pa zelu fine. In je muogla usaka hiša dvaj obvieznu. Je praj Napoleon šu, k-so tiste hruške rodile. Staru sadje kəsnu rodi. (Ožbolt 2004: 118-119, št. 254)

Da je zgodovinska verodostojnost vsebinskega motiva o sajenju hrušk v zadnji povedki vprašljiva, nakazuje povedka, ki ukaz o sajenju hrušk pripiše drugi zgodovinski osebnosti:

»Marija Terezija je zarad lakote zabičala, de mora usaka hiša met tepko, de bojo vsaj suhe tepke pozim za jest.«(Bokal 2010: 139, št. 336) ${ }^{11}$

Pogosta tema povedk so tudi nasilne vojaške konfrontacije s Francozi.

»Pred dvema letoma pri svojem stricu bivši, sim semtertje popotoval je marsiktere dozdaj svetu neznane kraje pustega Krasa vidil, ki hranijo v sebi prav imenitne zgodovinske spominke iz minulih časov. Pridem enega dne se šetaje do sterme, sterme doline, ki se na dnu z raznim drevjem obraščena ob kraju gole pečine proti visocemu hribu vzdiguje. Sama sterma

\footnotetext{
${ }_{11}$ Dejansko je v 18. st. sadjarstvo v nekaterih avstrijskih deželah začelo dobivati večji pomen. Iz tega obdobja so znani kazenski predpisi glede tatvine in poškodovanja sadnega drevja. Po ukazu Marije Terezije se je to začelo zasajati ob cestah (Valenčič 1970: 323).
} 
steza pelje v strašno globino. Kmet ondi stoječ mi pové sledečo prigodo. Ko so v letu 1814 francoski vojšaki iz Kranjskega bežali, se od avstrijskih armad pojeni v majhene trume razkropijo, kterim je naša narodna bramba vedno za petami sledela. Oddelk francozke armade blizo 1800 mož se loči od druzih, ter skoz Notranjsko proti morju beží. Pogumni Graničarji pa so jih neprenehoma podili, tako da se vsi Francozi izstradani in trudni v imenovano dolinico na počitek podajo. Cesarskim vdan kmet to zapazi in urno Graničarjem zakotek razodene. Hrabri Hervati obsedejo globino. Ravno se Francozi zarano dalej vzdignuti hočejo, kar začnejo horvaške puške pokati in kmalo so bli vsi Francozi premagani, da se je prelita kri scurkoma po dolinici točila. Odsihdob pravijo dolini ,kervava dolina“ in potoku, ki tam izvira ,kervavi potok‘.«(ISN, Kervava dolina, 1851)

»Kako so bili Francozi prevarani pri dvižnem mostu na Klužah, pa je pripovedovala tale verzija: Avstrijski vojaki so most dvignili. Sovražniki tega niso vedeli. Korakali so in drug za drugim padali v globok prepad. Šele ko je prišel do roba prvi konj, se je ustavil in ni hotel več naprej. Takrat so spoznali ukano.«(Arhiv ISN, Francozi, Tolmin, 1964)

Dogodkom, vezanim na trdnjavo Kluže, lahko sledimo tudi v zgodovinskih podatkih: prav v času francoskih vojn je namreč ta utrdba zopet pokazala svojo strateško vrednost.

Avstrijska oblast je grad popravila in utrdila in v njem se je leta 1797 nastanila vojaška posadka (Fortunat Černilogar 1993: 27). Kot je že leta 1882 pisal Simon Rutar (čeprav ni povsem jasno, na katere zgodovinske vire se je opiral niti ali se je naslanjal tudi na folkloro - op. A. M.) , je avstrijska posadka ob prihodu Francozov spoznala, da se pred njimi ne bodo mogli ubraniti. Ponoči je del posadke grad zapustil, ostali pa so odstranili nekaj mostnic, nasekali tramove in čakali. Francozi so, misleč, da je zapuščen, skušali grad zasesti še isto noč. V hitrem naskoku je del francoske vojske našel smrt v globoki soteski. Nato so podkupili nekega pastirja, da jim je pokazal pot do gradu, in ga napadli. Posadka se je v brezizhodnem položaju predala (Rutar 1882: 187-188). A hkrati je Rutar (1882: 81) opozoril tudi na povedko, v kateri je enaka usoda, kot je doletela Francoze pri padcu v globino, pripisana Turkom; glede na to, da je bila prvotna trdnjava na Klužah postavljena z namenom beneške obrambe pred Turki (Fortunat Černilogar 1993: 18), mešanje »francoskega« in »turškega časa« ni tako presenetljivo, in kot bo opisano v nadaljevanju, niti tako redko. Tu smo priča generalizirani drugosti v obliki napadalnih osvajalcev, pri čemer se lahko v vlogi slednjih pojavljajo različni liki iz kolektivnega spomina.

Čas francoske okupacije slovenskih dežel se v slovstveni folklori, ki sem jo zbrala, kaže v pretežno negativni luči. A če folkloro o Francozih primerjamo npr. s folkloro o drugih zgodovinskih osvajalcih slovenskega ozemlja, o osmanskih Turkih, je v povedkah o prvih manj izrazite krutosti, ki je značilna za opise turškega osvajanja, čeprav se v več povedkah ta čas opisuje kot težak - prihajalo je do ropanj, francoski vojaki so kmetom jemali hrano, streljali, požigali naselja, morili, plenili. Ob prvem prihodu Francozov na 
Slovensko je med prebivalci prišlo do velikega strahu. Premožnejši so bežali, ostali so se skrivali. Francoska vojska je bila zato prisiljena delovati pomirjevalno. Kmetje so morali, kot rečeno, prehranjevati francoske vojake, vendar je avstrijsko uradništvo, ki je ostalo na svojih položajih, stroške poravnalo (Granda 2012: 155).

Nekatere povedke pa, morda skladno s tem prvotno pomirjevalnim pristopom Francozov, pričajo o njihovi humanosti, prijaznosti in poštenosti.

»Sorodnik pripovedovalke (peti rod nazaj), imenovan nono Domenih, je bil trgovec in prevoznik v Bovcu. Vozil je blago iz Trsta na Dunaj. V času vdora Francozov je oskrboval tudi Napoleonovo vojsko na Predelu. Ko je dobil prvo povelje, naj pripelje blago Francozom, se je lepo oblekel in obul nove škornje, da bi se čim bolj postavil pred vojaki. Ko je prišel na Predil, so ga francoski vojaki sezuli, mu vzeli škornje in vrnil se je v copatah v Bovec.

Nono Domenih je po francoski invaziji obubožal, ker so mu vse blago pobrali, ne da bi mu karkoli plačali. Sicer so bili Francozi ,fajn, galant ljudje'. Ljudi niso preganjali, v vojsko pa so pobirali samo fante, ki so bili brezposelni. Nasilij torej niso počeli. Domačini so živino res odpeljali v hribe, le kakšno ovco in kozo so pustili doma. Te so seveda vojaki vzeli s seboj.« (ISN, Francozi, Bovec, 1964)

»Zlatnik v Bovcu. Ko so se Francozi vračali iz Rusije skozi dolino Trente, so se ustavili tudi v Bovcu. Trije vojaki so se zatekli na večer v neko hišo. Gospodinja je ravno pripravljala večerjo - močnik. Vsi lačni so posedli okoli ognjišča in prosili gospodinjo za močnik. Gospodinja jim je dala skledo močnika. Ko so pojedli, so dali v ponev tri cekine. Še danes je ohranjen en cekin v Bovcu. Nekateri vojaki so v Bovcu ostali ter se tam tudi poročili. O tem pričajo imena francoskega izvora v Bovcu.« (ISN, Francozi, Tolmin, 1964)

O naklonjenem odnosu do Francozov kaže tudi več povedk, ki izvor nekaterih prebivalcev v kraju, določene domačije ali družine pripisujejo francoskim vojakom, ki so se ustalili v naših krajih.

Kot pravi Gruden (1911: 24), je v času francoske nadvlade v slovenske dežele prišel marsikateri francoski obrtnik in trgovec in se nato tu naselil, prav tako so ostali tudi posamezni vojaki. Te povedke so morda odraz tega.

Odnos do Francozov se je torej spreminjal - kot rečeno, se je gibal od nasilnih konfrontacij do naklonjenosti. Gruden (1911: 21) je bil, podobno kot Kuhar (1964: 113), mnenja, da je bolj naklonjeni odnos odraz različnega odnosa do Francozov v vojnem stanju in poznejšem mirnem obdobju, deloma pa lahko to verjetno pripišemo tudi procesu demonizacije, med katerim pride do potenciranja krutosti, ki je značilno za vojni čas; pripisovanje krutega ravnanja vojaškemu sovražniku je že staro propagandno orodje (Rozhodestvenskiy 2013: 36-37). 
Povedke torej izkazujejo precej ambivalenten odnos do Francozov - ti so prebivalce slovenskih dežel ekonomsko izkoriščali, a niso bili brezsrčno nasilni kot npr. Turki in so v primerjavi z njimi prikazani v precej bolj človeški podobi. Toda na splošno so imeli Francozi med slovenskim prebivalstvom malo privržencev; med njimi so prevladovali izobraženci, reformno usmerjeni frankofilski uradniki in večji trgovci (Vodopivec 2006: 25-26). Večina slovenskega prebivalstva pa je Francoze ohranila v slabem spominu (Vodopivec 2006: 29).

Značilen primer slednjega so povedke, ki Francoze obtožujejo objestnega obnašanja do prebivalstva.

»Tukaj, pri nas, nad Bilpo v hrib so bile včasih zidanice in vinogradi. Na vrhu hriba so imeli vinograde in zidanice Kočevarji, spodaj pa mi. Vinogradov danes ni več.

Pravijo, da so prišli v naše kraje Francozi. Tudi v Bilpo. Zvedeli so za zidanice in kleti. Prišli so gor in streljali v sode, da je vino teklo ven, oni pa so pili. Niso pa mogli vsega popiti. Takrat je vino teklo doli po hribu in priteklo celo v Kolpo. Tako so pravili stari ljudje.« (Primc 1997: 333, št. 360)

»Francoz je prišel v hlev. Videl je lepega teleta in hotel jesti njegov jezik in prècej ga je moral gospodar pobiti, samo da se je on jezika najedel.« (Stele 2013: 126)

V okvir objestnega obnašanja Francozov bi spadal tudi nenavaden motiv francoskega vojaka, ki prisili mlado mater ali kmeta, da namesto otroka v zibelki ziba njega.

Študijo na temo zibanja francoskega vojaka je napisala Marija Makarovič (1955). Zbrala je 24 različnih variant te povedke (vzroki in spremljajoči dogodki zibanja se v njih rahlo razlikujejo). Ena od variant je sledeča:

»Francosk vojak je pršu h Resniku, je pa zibka tm zamerku pa se j not ulegu, pa j Resnik peu, an ga j zibu:

aja tutu, le spančki sladku - aja čiči, usaka reč le an cajt trpi.

Pol je pa francosk oficir pršu, je pa vojaka vn nagnou.« (Makarovič 1955: 155)

Kot eno od možnih razlag za ta nenavadni motiv Makarovičeva (1995: 159) navaja možnost, da kmet predstavlja nezadovoljno ljudstvo, ki potrpežljivo prenaša vse težave, ki jih povzročajo Francozi, ko pa mu je zadosti, se postavi po robu in vojaka zvrne iz zibelke. Variante povedke, ko se kmet pri tem po pomoč obrne na francoskega oficirja, bi lahko razložili z zgodovinskim dejstvom, da so Francozi skušali ohraniti red in mir v zasedenih deželah.

V večini povedk se pojavlja tudi rek »vsaka stvar en čas trpi«, ki pa je po mnenju Makarovičeve (1955: 159) obstajal že pred francosko zasedbo in je šele naknadno prišel v folkloro, v kateri nastopajo Francozi. 


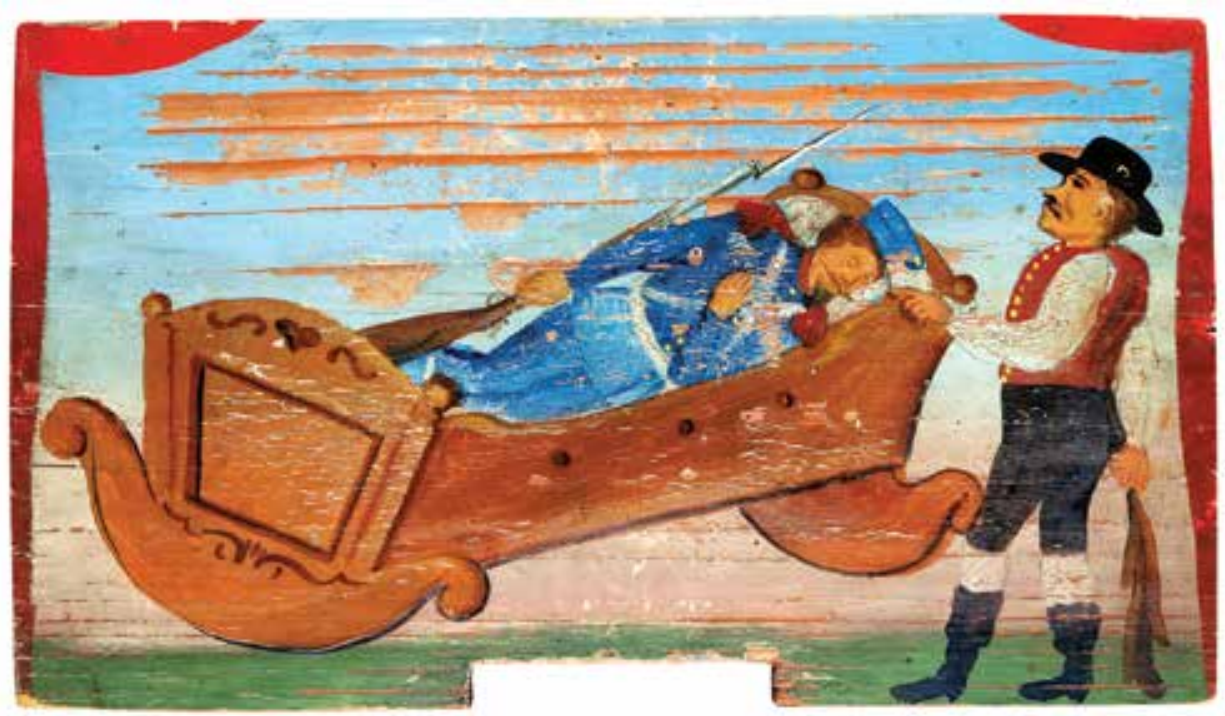

Kmet ziblje Francoza (motiv s panjske končnice, zbirke Slovenskega Etnografskega muzeja) ${ }^{12}$

Nadalje poskuša Makarovičeva (1955: 164-166) na podlagi vsebine povedk ugotoviti točno lokacijo, kjer naj bi prišlo do zibanja (po njeni ugotovitvi naj bi se to najverjetneje dogodilo pri kmetu Mlakarju z Mrzlega polja), in celo točno datacijo tega dogodka (meni, da se je gotovo zgodil v času obstoja Ilirskih provinc), ki ga torej dojema kot (bolj ali manj) resničen dogodek, ki pa je kasneje dobil simbolični pomen. Glede na naravo povedk, da se lokalizirajo in prilagajajo različnim okoljem, se mi tovrstno razpravljanje sicer ne zdi smiselno, vsekakor pa podaja nekaj zanimivih interpretacij tega resnično nenavadnega motiva. Dodaten dokaz o migracijski naravi te povedke in o nesmiselnosti iskanja resničnega dogodka v njenem ozadju lahko morda ponudi povedka, v kateri Turek prisili mlado mater, da ga ujčka v zibelki:

»Š́ je med okoličani živa pripoved, « je dodal kmet, »kako so Turki nekoč presenetili mater, ki je v zibeli ujčkala otroka. In ukazal je Turek ženski, naj dene otroka ven. Sam se je ulegel v zibel in zahteval od matere, da ujčka njega.« (Radešček 1983: 246-248)

Ta povedka ponovno pokaže, da v ljudskem dojemanju ni (vedno) razlike med »francoskim« in »turškim časom«. Naletela pa sem tudi na povedko, v kateri plemič prisili tlačanko, da vzame svojega otroka iz zibeli in ziba njega, ta pa ga, ko se naveliča, podobno kot se zgodi francoskemu vojaku, prevrne iz zibeli (Radešček 1983: 120). Torej gre morebiti za motiv, ki obstaja neodvisno tako od Francozov kot od Turkov, in je zato še toliko bolj brez pomena iskati v njem dobesedno zgodovinsko resnico.

\footnotetext{
${ }^{12}$ Ljudska umetnost je Francoze upodabljala na različne načine - na čebeljih panjih, panjskih končnicah, vratih, na freskah kmečkih domačij in gospodarskih poslopij (za pregled gl. Ferle 2009: 67-69).
} 
Sicer pa so Francozi v Štrekljevi zbirki omenjeni v 14 pesmih, predvsem v vojaških, enkrat tudi v ljubezenski kot »tatovi deklet«, v vseh ostalih pesmih pa so v skladu z zgodovinskimi razmerami (francosko okupacijo) opisani kot sovražniki (Bizjak 2000: 117). ${ }^{13}$

Francoze je zaznamovala tudi jezikovna drugačnost. Lahko si je predstavljati tudi jezikovne nesporazume med francoskimi vojaki in domačim prebivalstvom, o čemer priča več povedk - nekatere na humoren način, v eni pa francoska vojaka zaradi jezikovnega nerazumevanja ubijeta žensko. Humor je nekaj, kar v npr. folklori o Turkih opazimo v zgolj minimalni meri, o Francozih pa je nekaj povedk z izrazito humorno vsebino.

»U-Ribəncə de so blə Francuozə, so pərpoudvalə; de so probavalə slovenščino se učət pa so kašno tako besajdo, de so se pol əldje smejalə jəm. So mama mujà pərpoudvalə.« (Ožbolt 2004: 118, št. 253)

»K nam so prišli Francozi in prinesli ,drugačne čase‘. Tudi slabo smo jih razumeli, saj so govorili neki čuden jezik! Nekoč je prišel v hišo vojak in spraševal za oves, ki bi ga potreboval za konja, pa reče: ,Hopsa, hopsa“, namesto ovsa, ovsa. Gospodinja ni razumela, kaj vojak hoče, pa si je mislila, da hoče plesati z njo[,] in je to nakazala ... Ker se nista mogla sporazumeti, sta planila v smeh ...« (Ravbar Molato 2007: 134-135, št. 175; gl. tudi Verdinek 2002: 143, št. 211)

\section{MATERIALIZACIJA FOLKLORE O FRANCOZIH}

Pomemben sklop povedk o Francozih tvorijo tiste, ki so tesno vezane na fizični prostor - to sicer velja za povedko kot žanr na splošno, saj so vse umeščene v konkretni fizični prostor, a pri tem mislim predvsem na takšne, ki še dodatno poudarjajo materializirani vidik svoje vsebine, ki naj bi služil kot »dokaz« za resničnost zgodbe. ${ }^{14}$ Določene točke so tako opisane kot kraji, kjer so Francozi pokopani.

\footnotetext{
${ }^{13} \mathrm{~V}$ povedkah se vidik ljubezenskih odnosov med francoskimi vojaki in domačimi dekleti ne poudarja. Izjema je morda tale povedka: »Zgodilo se je pri Čargu - hiši, ki danes ne stoji več. Čargo je bil župan - ponosna, bogata družina - zato so jih tudi imenovali Goldčargovi. Ko so prišli Francozi v Tolmin, so se utaborili na Logu ob Soči. Častniki so se obrnili na Čargovo družino, naj jim pripravijo kosilo. Dekla jim je nesla kosilo v pletenici. Spremljala jo je domača hči, stara 14 let, ki je bila zelo lepa. Vsi časniki so si jo ogledovali. Ko sta se z deklo vrnili domov, je neki francoski časnik prijahal na konju za njima. Doma so imeli velik porton, tako da so lahko kar kočijo zapeljali v vežo. Tako je tudi časnik kar na konju prijahal v vežo. Ko ga je deklica zagledala, se je prestrašila in zbežala pred njim v kamro in se zaklenila.« (Arhiv ISN, Francozi, Log pri Tolminu, 1964)

${ }^{14}$ Fizične ostaline iz tega obdobja so raznolike. »Spomin na te čase [francosko okupacijo - op. A. M.] pa nam budijo ponekod tudi še ostanki francoskih okopov, na pokopališčih pa nagrobniki pri nas padlih francoskih vojakov. Dolgo pa so ljudje hranili še francoske sablje, puške in nože, francoske občinske grbe ter najrazličnejše francoske listine. Manjše krogle francoskih topov pa so imeli kmetje za uteži pri urah.« (Kuhar 1964: 101)
} 
»Mi imamo liêti [tukaj - op. A. M.] duôli tu - kokú riêčejo? Kršličje. In liêti, de so pokopani neki Francuózi bli. Kao, znači, lohku so bli Francuózi - tu bi bli Napoleonovi vojaki, drugi niê bi kaj - druga vuôjska nej tuód mimo šla.« (Pugelj 2012: 298, št. 556)

»Ja, so bli, ma so bli tudi od tiste francuóske vojsće. Tle duôli riêčemo, so bli Francuózi zekopani. Se riêče pa Kršličje. Tle samo pod našo vasjo duôli.« (Pugelj 2012: 300, št. 561)

»Pravijo, da sta blizu Jezerca v Žetini pri Lucijinem studencu dva Francoza pokopana.« (Dolenc 2000: 85, št. 245)

»Pri devici Mariji na polju - morda $1 \mathrm{~km}$ oddaljenem kraju od Bovca, so pred prvo svetovno vojno urejali park. Ko so sadili drevje, so našli v zemlji številna okostja in tudi nekaj orožja. Po orožju so sklepali, da gre za pokopališče francoskih vojakov.« (Arhiv ISN, Francozi, Bovec, 1964)

Če nekoliko podrobneje pogledamo zadnjo povedko, lahko vidimo, kako folklora ustvarja lastno vez med zgodovino in kolektivnim spominom. Sicer zaradi pomanjkanja kontekstualnih podatkov tega ni mogoče z gotovostjo preveriti, se pa ta lokacija morda nanaša na cerkev Device Marije na Bovškem polju, kjer so na travniku Gomilica pri izravnavi zemljišča našli človeške kosti z ogrlico koščenih in steklenih jagod okoli vratu in posodo, datirano v konec 8. ali v 9. st. (Arheološki kataster Slovenije = ARKAS, ID 101102.08). Možno je torej, da se je ta arheološka najdba interpretirala v povezavi S »francoskim časom«, saj je to omogočilo najustreznejšo razlago za najdeno. Da pa je omemba Francozov v folklori lahko tudi arheološko indikativna (s čimer se ne strinja Slapšak (1995: 19), ki meni, da etnikoni, kot so francoski, ciganski, hrvaški, nemški, kažejo na mlajše zgodovinske stike in niso zanimivi za arheološko topografijo), kaže tudi primer arheološkega najdišča z imenom Francosko grobišče. Najdišče sicer ni datirano, gre pa za grobišče (ARKAS, ID 050230.00). A to je zgolj primer toponima, za katerega ni nobene (znane) povedke, zato ne želim posploševati. Dejstvo pa je, da so povedke o Francozih močno vpete v fizično krajino. Kakšna je zgodovinska resnica za posamezen primer, bi bilo treba pogledati za vsakega posebej, pri čemer pa bi bila potrebna terenski pregled in študija zgodovinskih virov, kar pa presega namen tega prispevka. Želela sem zgolj pokazati, kako povedke kljub videzu zgodovinske resničnosti te ne odražajo vedno. Namreč, skupnost lahko določenim objektom v prostoru ali samim krajem doda atribute drugosti. Pri tem gre lahko za drugost iz preteklosti, ki jo skupnost ohranja v svojem kolektivnem spominu in se kaže v prostorskih točkah, ki so resnično imele povezavo s preteklim dogodkom, na katerega je skupnost navezala določeno naracijo svoje preteklosti, lahko pa so te točke z vidika historične realnosti zgolj namišljene - to so t. i. kraji spomina oz. lieux de mémoire (termin, ki ga je uvedel Pierre Nora; gl. Nora 1989), v katerih so koncentrirani različni zgodovinski pomeni. Te točke služijo kot mnemotehnična sredstva, ki priklicujejo v spomin (zgodovinsko resnične ali namišljene) dogodke iz preteklosti 
skupnosti, s tem pa služijo kot učinkovita orodja utrjevanja njene identitete. Skozi te materializirane točke drugosti Francozov (ne glede na to, ali so dejansko povezave s tem zgodovinskim obdobjem ali ne) torej folklora torej vedno znova prikliče spomin na »francoski čas«, s tem pa se evocira skupno preteklost in potrjuje lastno identiteto skupnosti v odnosu do te drugosti (gl. Mlakar 2016: 110). In morda je toliko sledov drugosti $\mathrm{v}$ prostoru prav zato, da predstavljajo nenehen opomnik na identiteto lastne skupnosti.

Tesno so na prostor vezane tudi povedke, ki govorijo o infrastrukturnih objektih, ki naj bi jih zgradili Francozi.

»Napoleonovi vojaki so delali cesto od Brezovice pa do Vinice. Od radenske kapelice do Daleh njiv je iše Napoleonova cesta. Označena je iše s cestnim kamnom.« (Kure 2004: 79, št. 157)

»Uod Francuozu je pa Renkoč must. De so ga Napoleonovə pionierjə gradilə.« (Ožbolt 2004: 118, št. 254)

„ Še tu je Rjenko povajdou, je rieku: ,Lej, ta must so pa napoleandrə gradilə. Tridesiet grenadirju je blu!' Tistə must ... Je rieku: ,Še je lajtənca nuotrə, taužənt uosəmstu deviet al je desiet. '

So blə pa Napoleonovə grenadirjə, tu se pravə inženiercə, ne, in so ga uoni zgradlə, ne. Zgradlə so ga pa zetu, ker je imu Kuočeuskə grad tla dostop. So blə poúdnə, praj je bieu ləsien must in so pokazalə solidarnost do kuočouskəga grada, taku de so pualaj ta must neriedlə.« (Ožbolt 2004: 119, št. 255)

»Must je pa Napoleon neriedu tisočuosəmstuuasməga lajta in je še kamən. Je kamən uklesan in lajtənca, samu se je kar najkaj zgubu nuotrə u-ziemlo, ga naj vidət.« (Ožbolt 2004: 119, št. 256)

Kako je z zgodovinsko verodostojnostjo teh podatkov, bi bilo, kot rečeno, treba preveriti za vsak primer posebej, kar pa bi zahtevalo več ločenih raziskav. Zadnje tri zgodbe omenjajo most pri Renkoču. V Registru nepremične kulturne dediščine (evidenčna št. enote 23718) je opisan kot »triločni kamniti cestni most na Velikem Obrhu«. Zgrajen je bil v prvi četrtini 19. st. in naj bi ga, kot je navedeno v registru, po izročilu leta 1810 zgradili Francozi. Dejstvo je, da je bilo konec 18. in v začetku 19. st. (posebej na Primorskem) zgrajenih veliko kamnitih mostov, ki so jih ljudje poimenovali Napoleonovi mostovi, zgodovinsko zanesljivost njihove povezave s Francozi pa je težko preveriti zaradi pomanjkanja podatkov (Humar 2012: 55). ${ }^{15}$ Dejansko pa je pod francosko oblastjo prihajalo do infrastrukturnih posegov, npr. vzdrževanja in popravljanja cest ter mostov

\footnotetext{
${ }_{15}$ Podobno tudi Napoleonov most čez Nadižo pod Logjem pri Podbeli, datiran v prvo četrtino 19. st. (RNKD, evidenčna št. enote: 5068), ki naj bi, po folklori sodeč, dobil ime po Napoleonovih četah, ki so ga prečkale (Dular, Podpečnik, Šumrada 2010: 421).
} 
(samo na Kranjskem so vzdrževali 140 milj cest, 23 velikih in 70 manjših mostov) ${ }^{16}$ (Holz 2010: 100). V kategorijo materializirane folklore uvrščam tudi povedke, ki govorijo o gradbenih podvigih Francozov.

Povedke velikokrat govorijo o kraju, ki ga Francozi na neki način zaznamujejo, npr. (podobno kot pri Turkih) kraji, kjer so taborili (prim. Pugelj 2012: 300, št. 562), prostorske točke, ki so jih zaznamovali s svojo prisotnostjo (prim. luknje v stenah cerkve - Kotnik 1957: 66-67; kamen z »Napoleonovimi črkami« - Zupan 1999: 68, št. 95; miza, za katero je sedel Napoleon - Arhiv ISN, Francozi, Lozica), najdbe podkev francoskih konj (prim. Primc 1997: 335, št. 362; Stanonik 2001: 339, št. 436; Stele 2013: 127), drugih ostalin iz tistega obdobja, kot so npr. francoski denar (prim. Stanonik 2001: 339, št. 436), človeške kosti, orožje (prim. Kotnik 1957: 66-67; Stanonik 2001: 340, št. 437), ali pa, kot rečeno, grobov, kjer naj bi bili pokopani francoski vojaki.

»Tista cesta, tisti kuós cejste še dənəs vidən in tam, kəmər so Francuózi, kəmər so taborili, se tudi še zmiérej vidi. Nê tabor, ampak parcela je še zmiérej tam.« (Pugelj 2012: 300, št. 562)

»Prav tu, kjer je avtokamp, je bila tudi borba s Francozi. Vojaki so imeli tudi konje. Še pred desetletji so tu našli konjske podkve in kopita. Takrat so Francozi zasedli grad Poljane v Predgradu in ga zaradi upornih Poljancev oplenili in zažgali.« (Primc 1997: 335, št. 362)

»Francozje so bili povsod na kvartirju, samo v Tunjicah ne. Le s konji so enkrat šli skozi. Še moj oče je njihove podkve našel. Med našo hišo in Tunjščico je namreč frajka, poglóbnica, kjer so nekdaj vsi pasli. Tam se je konjem udiralo, pa so podkve pogubili. Imele so široko obliko, samo v sredi je bila majhna luknja.« (Stele 2013: 127)

\section{»FRANCOSKI ČAS « IN »TURŠKI ČAS«: ODNOS MED FOLKLORO IN ZGODOVINO}

Omenjenih je bilo že nekaj primerov, ko se v enaki pripovedi enkrat pojavijo Francozi, drugič pa Turki oz. ko razlika med »francoskim« in »turškim časom« ni povsem jasna.

Primer slednjega, ki ga lahko opredelimo kot težnjo v folklori, da se vse zgodovinske napadalce spravi v eno kategorijo, je sledeča pripoved:

»Anka Francoze (morda Turke) u Padno neso šle, ke so Padenjšce pulile gnojnico okulən vase. Ta se je stekla dol h pote eno Francoze so rekle: „Eeee, će te taku smrdi, kaku more ten gor?‘ " (Morato 2002: 84)

\footnotetext{
${ }^{16}$ Krajši pregled tovrstne nepremične dediščine je naredila Mojca Ferle (2009: 69-70).
} 
Tudi Zmaga Kumer (1957: 17-18) je ugotavljala, da je lik Francozov mlajši dodatek v folklori. Primer lahko vidimo v naslednjih dveh pesmih:

Na polju ljubljanskem

Armada stoji:

So lepi tam fantje,

So s kranjske zemlje,

So v službi cesarski,

Na Francoze gredó.

Francoz jim odpiše,

Da se nič ne boji.

Na to se jokajo

Ljubljanske gospé:

,Pomagaj Marija

Iz Šmarne goré,

Pomagaj Marija,

Ki v tronu sedi,

Preljubega Sina

V naročju drži!'

(SNP V/7184)

\section{Ljubljanca, Ljubljanca \\ Kako se tamkaj godi? \\ Okoli Ljubljance \\ Armada leži.}

So lepi, so mladi,

S hrvacke zemlje;

Cesarja služijo

Na Turka grejo.

Turek jim piše,

Da se jih ne boji.

Na to se jokajo

Ljubljanske gospé:

,Pomagaj Marija,

$S$ Šemarne goré,

Pomagaj Marija,

Ki v tronu sediš,

Preljubga svoga Sina

V naročju deržiš!

Pomagaj, Marija

$S$ Šemarne gore,

Pomagaj, Marija,

V te grozni vojske!"

(SNP V/7185)

V drugi različici so Francoze zamenjali Turki in fantje so »s hrvacke zemlje«, razlog za to pa je po mnenju Zmage Kumer (1957: 18) vpliv bližnje Vojne krajine v Suhorju, kjer je bila pesem zapisana, in še živ spomin na turške vpade.

Folklora preteklosti ne dojema po enakih časovnih načelih kot zgodovina, zato lahko združuje vsebine in osebnosti iz povsem različnih časovnih obdobij. Zato ni nenavadno, da se npr. $\mathrm{v}$ istem prostoru $\mathrm{v}$ podobnih povedkah enkrat $\mathrm{v}$ isti vlogi pojavijo Turki (ki so jih v nekaterih primerih zamenjali psoglavski vojščaki gl. Šmitek 2005: 6), drugič pa npr. Atila oz. njegovi Huni ali Francozi, ki so bili v zgodovinsko dogajanje na področju Slovenije vključeni v povsem drugih časovnih obdobjih (gl. González Álvarez 2011: 138; tudi Božović 1977: 217). A v folklori to niti ni pomembno - važno je predvsem ločevanje med Nami in Drugimi, v vlogi katerih se lahko pojavljajo različni tujci. Prav 
tako lahko prihaja do združevanja in mešanja močno oddaljenih časovnih obdobij, saj slovstvena folklora v nasprotju z zgodovino in tudi arheologijo preteklosti ne dojema $\mathrm{v}$ jasno zamejenem kronološkem okviru (podrobneje o tem gl. De Pina-Cabral 1989; tudi Hrobat 2007, 2010). Folklora teži k najnovejši in s tem najrazumljivejši manifestaciji, s katero želi predati določeno sporočilo, oz. k manifestaciji, ki je najrazumljivejša izkustvu posamezne skupnosti (gl. Layton 1999: 27; González Álvarez 2008: 239-240; 2011: 144; Slapšak 1995: 19). To lahko opredelimo kot težnjo k aktualizaciji, ki se v izročilu o tujcih kaže v tem, da »aktualnejši« liki zamenjajo starejše (npr. Turki včasih zamenjajo Saracene ali psoglavce; gl. Šmitek 1986: 293; 2001: 2), kar je mogoče opaziti tudi v kontinuiteti med tradicionalno in »sodobno« folkloro (gl. Tangherlini 1995). Značilna je tudi težnja po generaliziranju, ki je zelo pogosta v identitetnih procesih - tako so npr. barbari postali enotna skupnost oz. kategorija, individualne poteze posameznih ljudstev v tej vlogi so se zabrisale. In prav zaradi tega, pravi Krekovičová, ker predstave v folklori niso nujno urejene strogo kronološko, ampak se nalagajo druga na drugo, je treba drugost, ki se kaže v ustnem izročilu, vedno proučevati $v$ kontekstu določenega zgodovinskega obdobja, v katerem je to izročilo obstajalo (Krekovičová 1997: 167-168). ${ }^{17}$ Skupnost svojo preteklost umešča v čas »zgodovinskih Drugih«, četudi je velik del zgodovinskih elementov v tej folklori fiktiven. Kolektivni spomin si namreč z njihovim prisvajanjem zagotavlja smiselno celoto, ki lokalne dogodke povezuje z dogodki širše skupnosti (Brumen 2000: 29).

Odnos med folkloro in zgodovino je torej kompleksen in iz slovstvene folklore ne moremo pridobivati faktografskih dejstev kot iz zgodovinskih virov, lahko pa izkazuje stališča, mišljenja in ocene o določenem zgodovinskem dogajanju, a na svoj lasten kreativen in posreden način. Vsi pripovedni žanri lahko izkazujejo sledove preteklosti, je pa to najbolj izrazito $\mathrm{v}$ tistih izročilih, katerih vsebina se nanaša na zgodovinsko dogajanje (Bošković Stulli 2002: 12-13). Spremembe v slovstveni folklori so posledica tega, da v izročilo prihajajo elementi sodobnega (trenutne družbene razmere, mentalitete ...). Obledele spomine na neke prejšnje čase nadomešča trenutna slika sveta (Detelić, Ilić 2006: 13). Prav tako je v folklornih zgodbah zelo očitno, da odsevajo regionalne, etnične, kulturne, zgodovinske in prostorske značilnosti posameznega kraja oz. se jim vsebinsko prilagajajo (Bošković Stulli 2002: 15, 20-21; gl. tudi Šmitek 2009: 135). Prav tako v procesu t. i. tipizacije posamezne zgodovinske podrobnosti, ki so morda tvorile podlago nekega izročila, izgubljajo svoje individualne lastnosti in postajajo splošne, hkrati pa se lahko tudi sama zgodba umesti v novejšo oz. trenutnim nosilcem folklore razumljivejšo zgodovinsko situacijo (Stanonik 2008: 98-99).

Nejasno mejo med »francoskim« in »turškim« časom izpričuje tudi naslednja povedka:

\footnotetext{
17 Tovrstno »stapljanje spomina« na dogodke iz povsem različnih zgodovinskih obdobij se ne izraža zgolj v folklornih predstavah o Drugem: v skandinavski folklori npr. so vojne pustile močan pečat, se pa v njej ne prikazujejo v lastnih, časovno ločenih okvirih, ampak se stapljajo ena v drugo, ne glede na to, ali se zgodovinsko gledano umeščajo v 16. ali 19. st. Podobno so se tudi spomini na velike epidemije, ki jih je Skandinavija doživljala skozi stoletja, spojili oz. združili v folklorno tradicijo o črni smrti, ki je v 14. st. pomorila tretjino švedske in dve tretjini norveške populacije (Kvideland, Sehmsdorf 1988: 344, 352).
} 
»'Viš, tle je, se reče, Krvavə puôtək. Sou pravlə starə ldjé, de je bla tle ana štrəšna stvar. Ana huda bitka. Táku, de je blu, de je kri tekla v potuóćih.' Je djal, de suo se tuklə z dujmə sabljamə. De suo ležalə mrtvə po celə gmajnə. De suo se poklalə in ubilə. Je rieku [stric - op. A. M.] muôjmə atetə, de se fúrmanəm, ki vózjuo tuotlè ponuôći, večkrət kej pərkaže. Vsesuórt, de sou već vidlə, lüčce in tüdə veliće preciésje prez glav. Ne znam, katiera uôjska be tu bla. S Francuózə? S Türći? Aj, ma ne ne! Káka še bəlj od hedú názej. Zetu, ki od teh uôjsk ba se kej bəlj znalu. Ledjé sə zepúnejuo dugu.« (Tončič Štrancar 2005: 147, št. 123; gl. tudi Arhiv ISN, Kervava dolina, 1851)

Pri zadnji povedki se kaže, da v folklori ni večje razlike med časom Turkov in Francozov. Obema je skupno, da gre za obdobji vojaškega osvajanja, ki sta se v folklori spojili še s predstavami o vračajočih se pokojnikih (o čemer bo govor v naslednjem razdelku), in $\mathrm{v}$ tem oziru jasno ločevanje med njima niti ni nujno potrebno.

»Hudi so bili časi francoskih vojakov. Tudi po koroški deželi so mogočno razsajali, najbolj pa v Rožu.

Prihruli so čez Kočno v Črvič, v Sveče in v našo dolino. Toda nikoli ne bi prišli v te pokrajine, ako ne bi bilo na Kranjskem izdajice. Doma je bil v Savi pri Jesenicah, kjer je imel veliko graščino, ki še dandanes tam stoji. Francozi so mu ponudili vrečico denarja. Žvenk in cvenk ga je premotil in prodal se je sovražniku ter mu pokazal pot preko Golice na Kočno. Začetkoma se mu ni godilo slabo pri Francozih, kajti dokler niso bili gotovi, da najdejo pravo pot, so ga kaj častili. - Dospeli so že na koroško stran. Pohlepno so gledali po rodovitni dolini, po vaseh in zelenih livadah. Do ,prvih bajt‘ so še precej srečno hodili, nobena nesreča se jim ni pripetila. Ali zdaj jih je Bog kaznoval. Od zadnje planine (pašnika) na Kočni vodi črez precej dolg in zelo strm plaz, samo za kaki dve pedi široka steza do ,Koblahove peči‘. Po tej so morali tudi Francozi iti. Steza se je začela udirati, konji in pešci so popadali v brezno, iz katerega ni bilo več rešitve. Trudni, spehani in jezni so dospeli do Črviča. Vojaki so šli dalje, njih poveljnik pa se je na Črviču odpočil. Ko je spočit odhajal, je udaril s sabljo bled od jeze na skalo ter rekel: ,Nikoli več ne bom hodil po teh hribih in dolinah.“ A križ, ki ga je vsekal s svojo sabljo v skalo, se še sedaj vidi. Tudi jaz sem ga videl, ko smo hodili isto pot na Jesenice in Brezje.

Ko so prišli v dolino, so privezali izdajico z vrvjo $\mathrm{k}$ mizi in ga suvali $\mathrm{z}$ nogami, dokler ni poginil. Tako zadane smrt vsakega izdajalca.

Francozi so nato dospeli na Bistrico, kjer so oblegali na malem griču cerkev, ki ji pravijo ,pri križah‘. Streljali so v cerkev; luknje v stenah se še sedaj vidijo, ker jih ne morejo zazidati.

Ko so Bistričanje kopali neki rov, so našli sablje, gumbe in drugo starino, kar je izza francoskih vojsk.« (Kotnik 1957: 66-67) 
Ta zadnja povedka vsebuje več vsebinskih motivov, ki spominjajo na zgodbe o Turkih (steza se začenja udirati, poveljnik udari s sabljo v skalo in obljubi, da se ne bodo več vrnili v te kraje, sled udarca sablje še vedno vidna, Francozi oblegajo cerkev, najdeni ostanki francoske vojske; gl. Mlakar 2016) - povsem možno je, da gre v tej povedki za primer aktualizacije, kjer so Francozi v zgodbi nadomestili Turke.

\section{FRANCOZI IN »NADNARAVNA«DRUGOST}

Velik del folklore o Francozih je sestavljen iz motivov, ki nas na prvi pogled nekoliko oddaljujejo od historičnega in spominjajo na motive, ki jih lahko srečamo tudi v povedkah, ki se ne nanašajo na Francoze. Povezovanje Drugega z nadnaravnim je sicer značilno (Lindow 1995; Belova 2007), saj ta na neki način prihaja z onega sveta.

»Jelenovi pod Plešivcem so sedeli pri večerji, ko je stopil v sobo tujec in naročil polič vina. Stari Jelen je imel to dobro navado, da je prenehal takoj s kosilom ali z večerjo in precej postregel vsakemu gostu. Na pragu pred kletjo se je ozrl nazaj proti Peci, češ, kakšno bo le jutri vreme. Začel je klicati vse hlapce, dekle in domače, ki so tudi takoj prihiteli pred hišo gledat, zakaj jih je gospodar klical. Videli so v zraku na vrhu Pece žarečega vojaka na konju, ki je mahal z gorečim mečem na vse štiri strani sveta. Vsa družina je pokleknila in zmolila, obrnjena proti Peci, ves rožni venec. Nato je prikazen izginila.

Še tisto leto se je pričela strašna francoska vojna.« (Kotnik 1957: 215)

»V Mostah je bila ta vélika francoska druhal. Naša armada je pa na Homec prišla in se postavila okrog hriba in pri cerkvi. Naš general je šel na Homcu okrog oltarja in en bel denar v lampico spustil, kjer večna luč gori. Nato so naši na Francoze padli. Od Homca tja se je kar megla potegnila in nanje padla. In so tako bežali, kar je kdo mogel, za véliko cesto proti Lukovici in Blagovici. Pavri pa so jih kar pobijali.« (Stele 2013: 128)

Zadnja zgodba je podobna zgodbam o čudežnih rešitvah pred Turki, v katerih je nadnaravna sila preprečila turški napad. Namiguje na pomoč krščanske višje sile (kar je v folklori o Turkih zelo pogosto), ni pa v konfrontacijah s Francozi opaziti superiornosti religije, saj tu ne gre za religijsko dihotomijo kot pri Turkih. To pa je tudi edina povedka $\mathrm{s}$ tem tematskim motivom pri Francozih - bitke $\mathrm{z}$ njimi so v tem oziru predstavljene $\mathrm{v}$ bolj realni luči, brez posegov nadnaravnega, ki se sicer v zgodbah o Francozih kljub temu večkrat pojavlja.

»Je viêlək nesip in puôtlej je must. In če si ne tisti must pol, si čol francuóske vojake, ki so po cesti maršié in pejli. In z lučkami so bli. Veš. Tu je ku de bi en spomin [znamenje umirajočega ali umrlega, ki se na določen način 
poslovi od svojca - op. Pugelj 2012: 140], pa ne vem, de bi kej hudga delali ti francuóski vojaki, ampak vseenu en tak - ena taka pravca je bla, no. Čəš de se francuóski vojaki vicajo.« (Pugelj 2012: 139-140, št. 217)

»Jes pravəm, de kulku imam təh spominu səz starəh starəh cajtu. Pa veš, od təm pa imam spomine, tüd' takeliê - recimo Napoleon, je bil v təh krajəh, niê. In Meriéče so tokú malu ne poluóžnəm in puôtlej je železənca, grə mimu in puôtlej an kilometər duôli je pa cejsta. In so djali, de se huódijo francuóski vojaki vicat. De če grəš ne železənco in pošlušaš, de čuješ mašiéranje təh francuóskəh vojaku. Čəš, de so verjətnu delali tle grozodejstva in de so se jəh lediə bali, in de se huódijo nezaj. De huódijo nezaj in de se jəh čüje.« (Pugelj 2012: 140, št. 218; gl. tudi Pugelj 2012: 140, št. 219; Tončič Štrancar 2005: 147, št. 123)

Francozi kot Drugi in s tem na neki način pripadajoči onemu svetu so torej prešli v verovanja o vračajočih se pokojnikih oz. dušah, ki se vicajo. ${ }^{18}$ Pri tem gre za pojmovanje »dobre $\ll{ }^{19}$ in »slabe (in s tem povezano »čiste $«$ in »nečiste «) smrti, pri čemer pri slednji pokojniki ne morejo dokončno prestopiti v oni svet ter lahko v takšnem stanju škodijo živim, ostanejo povezani s tostranstvom in postanejo »hodeči« pokojniki, vampirji ali demonska bitja (Vinogradova 1999: 48). Tudi lučke, ki jih omenja ena povedka (Pugelj 2012: 139-140, št. 217), se lahko v tem kontekstu interpretirajo kot duše umrlih (Šmitek 2003: 5). ${ }^{20}$

Drugi in nadnaravno sta pogosto povezana (Belova 2007), mrtvi pa so s svojo pripadnostjo onemu svetu najbolj elementarni Drugi (Matteoni 2008: 139). Kaže, da se je tukaj folklora o Francozih kot (etničnih) Drugih spojila s tradicijskimi predstavami o tem, da se duše umrlih, »vicane duše « ali duše »nečistih umrlih «, lahko kažejo v podobi luči (Šmitek 2003: 5; Kropej 2008: 276, 283; gl. tudi Mencej 2006: 210-213). ${ }^{21}$

Z onostranstvom so Francozi povezani tudi v zgodbah o zakladih. Ti pripadajo onemu svetu (gl. Hrobat 2010: 54; tudi Champion, Cooney 1999: 198), v primerjavi s turškimi zakladi (ki so zelo pogosti v povedkah o Turkih), katerih najdbo vedno prepreči nadnaravna sila (razlag, zakaj so ti poskusi večinoma neuspešni, bi lahko bilo več, nimajo pa zveze z zgodovinsko realnostjo turških vpadov ali francoskih osvajanj ${ }^{22}$ ), pa so v zgodbah o

\footnotetext{
18 Duše nekaterih pokojnih so bile zaradi hudih pregreh za časa življenja zavdane ali uklete in so se kot nočne prikazni klatile tam, kjer so storile krivo dejanje. Tovrstni povratniki se najpogosteje prikazujejo na krajih, ki so jih obiskovali v tostranstvu. Gre za t. i. »nečiste umrle«, ki po smrti ne najdejo miru in so obsojeni na prestajanje kazni in čakanje na odrešitev, ki bo najpogosteje prišla šele na sodni dan. Vicane duše naj bi se prikazovale tudi v mrtvaški procesiji kot skupina brezglavih ljudi pri nočni maši, kot pastir sredi žareče črede ali pa kot nočna jaga. Odrešiti naj bi jih bilo mogoče z molitvijo, romanjem in postom, z izpolnitvijo njihove prošnje, s pravilnim odgovorom na njihovo tarnanje, k odrešitvi pa naj bi pripomogli tudi blagoslovljena voda, molitev in poravnanje krivic (Kropej 2008: 276, 279, 282).

19 Pri »dobri« smrti gre za nenasilno smrt, do katere pride v starosti, ko je človekova vitalna sila naravno izčrpana. Po takšni smrti lahko pokojnik mirno preide na oni svet (Vinogradova 1999: 46).

20 Več o tematiki luči kot duš umrlih ali bajnih bitij gl. Mencej 2006: 210-226.

21 Zelo pogosto pa so, kot ugotavlja Mirjam Mencej (2006), svetlobni pojavi pripisani čarovnicam.

${ }^{22}$ Tu bi lahko upoštevali teorijo Georga Fosterja (1965) o »omejenem dobrem« (angl. »limited good«), ki pravi, da je količina dobrin omejena in da v družbi lahko nekdo dobi več dobrin zgolj na račun drugega. Vse,
} 
francoskih zakladih (pogosto v obliki vojaške blagajne) pogosto najdeni (ne pa vedno včasih ljudje, kot pri turških zakladih, zaman kopljejo, da bi jih našli) in ljudje se z njimi materialno okoristijo. Morda je to povezano z večjo časovno bližino bojev s Francozi in njihovo bolj realno podobo v zgodovinskem spominu v primerjavi s Turki ali pa je, kot meni Gruden (1911: 22), to oddaljen spomin na resnične napade na francoske vojaške blagajne ali pa na to, da so si nekateri ljudje s prevažanjem blaga ali preskrbo francoske vojske pridobili precej premoženja (lahko to imenujemo vojno dobičkarstvo?) in se je nato to v folklori odražalo kot »najdba francoskega zaklada« (gl. tudi Granda 2012: 159).

»Tam, pri taborski cerkvici, je ena jama, Kevdrce se imenuje. Pa je en pijanček kopal tam v Kevdrcah. Nakopal je že šest kubičnih metrov zemlje. ,Stric, notri je šac!‘ je rekel. ,Stric, sem zvedel, ko so se tu Napoleonovi vojaki umikali, da so zakopali tukaj zaklad, saj so se morali hitro umakniti.‘ Pa je kopal in kopal, pa šaca ni nikoli našel.« (Samec 2014: 113, št. 118)

»Pod Švavnarjevim znamenjem je hlapec vozil gnoj na šefrsko njivo. Mimo je prijahal francoski soldat, ki je imel na konju lodrico denarja. To lodrico je na cesti izgubil, hlapec, ki je peljal za njim, jo je pa zvalil na njivo in pokril z gnojem. Ko je soldat zamerkal, kaj je izgubil, je prijahal nazaj in iskal lodrico, a je ni mogel najti, ker je bila pod gnojem. Hlapec je kasneje odkidal gnoj z lodrice in tako postal bogat. Kupil je pôl dom pri Šefarju.« (Dolenc 2000: 85, št. 247)

\section{SKLEP}

Kot je bilo prikazano v članku, se vsebina povedk o Francozih v mnogočem sklada z zgodovinskim dogajanjem v času francoskega ovajanja slovenskega teritorija in Ilirskih provinc. Odražajo predvsem breme preskrbe francoske vojske, davčnih obveznosti in materialnega izkoriščanja, jezikovno drugačnost Francozov, manj govorijo o strožjem pravnem redu za časa Francozov, medtem ko o nekaterih drugih vidikih francoske oblasti (npr. verske reforme, upravne spremembe) ne povedo ničesar. Poleg zgodb o nasilnih vojaških spopadih s Francozi se pojavljajo tudi takšne o manj agresivnih, bolj naklonjenih odnosih, kar bi lahko bilo posledica težnje Francozov po čim bolj mirni zasedbi, hkrati pa je lahko bolj naklonjen odnos odraz mirnejših obdobij francoske okupacije. Na splošno lahko rečemo, da Francozi na podlagi povedk, ki jih lahko povežemo z zgodovinsko realnostjo, izstopajo predvsem kot vojaški osvajalci, njihova etničnost oz. etnična drugačnost ni v ospredju (delno jo poudarjajo predvsem povedke, ki se nanašajo na jezikovno drugačnost).

kar grozi prekinitvi statusa quo v družbi, je sankcionirano (ali pri iskanju zakladov - neuspešno). Podobno idejo ima Reboredo (1983: 19; v: Parafita 2006: 136), ki pravi, da mora družba svojo socialno uravnoteženost braniti pred ambicijami posameznika, ki lahko potencialno povzročijo zlom socialno-ekonomskega stanja $\mathrm{V}$ družbi. María Del Mar Llinares (1990a: 35) pa neuspeh pri iskanju zakladov pripisuje negativnemu vrednotenju bogastva, ki je bilo pridobljeno brez truda in dela. 
Našla sem tudi en primer zgodbe o Francozih kot prenašalcih bolezni, a ga zaradi njegove edinstvenosti nisem izpostavljala. ${ }^{23}$ Tujci, pripadniki tujega sveta in potencialni prinašalci nevarnih sil in moči, nam namreč lahko škodujejo kot prinašalci bolezni - to je v slovstveni folklori pogost motiv (gl. Tangherlini 1988: 187-188).

Da pa odnos med zgodovinskim dogajanjem in folkloro ni vedno enoznačen, kažejo primeri, ko se v enaki zgodbi ali v povedki z enakim vsebinskim motivom enkrat pojavijo Francozi, drugič pa Turki - njihovo medsebojno zamenjevanje je logično, saj so v zgodovini oboji nastopali kot vojaški zavojevalci, poleg tega pa so bili Francozi prva sovražna vojska, ki je stopila na slovenska tla po koncu turških vpadov ${ }^{24}$ (Šumrada 2010: 24). Da se pripovedi o Turkih stapljajo s pripovedmi o Francozih, je že pred več kot stotimi leti ugotavljal Josip Gruden (1911: 1). Pri tovrstnem stapljanju skladnost z zgodovinsko resničnostjo ni v ospredju. Lahko sklepamo, da ne glede na to, da se v določenem primerku slovstvene folklore pojavljajo enkrat Francozi, drugič pa Turki, ta folklora nagovarja določene potrebe skupnosti, ki si podobo zgodovinskih Drugih zgolj izposoja, da prispevajo videz resničnosti in zgodovinskosti ter podajajo odgovor na vprašanja, ki se ji postavljajo z vidika njene lastne identitete in preteklosti. Folklorist Brynjulf Alver (1989) je bil mnenja, da z vrednotenjem kvalitete in vrednosti folklore s stališča »zgodovinskosti« zgrešimo prave razloge, zaradi katerih ta folklora živi in se širi med ljudmi. Osredotočiti bi se morali na kulturne in emocionalne pomene, ki jih prinaša. Slovstvena folklora z zgodovinsko tematiko ne predstavlja toliko odmeva zgodovinske resničnosti, pač pa predvsem interpretacijo (morebiti resničnih) dogodkov $z$ vidika skupnosti skozi lečo tradicionalnih predstav (Kvideland, Sehmsdorf 1988: 329).

Po drugi strani je lik Francozov prešel tudi v tradicijske predstave o vračajočih se umrlih, torej so postavljeni v vlogo najbolj elementarne drugačnosti, v vlogo nadnaravnega Drugega, v drugost, ki jim je pripisana kot pripadnikom onega sveta in se kaže v obliki nadnaravnih pojavov, kot je vicanje njihovih vojakov. Njihova nadnaravna drugost se odraža tudi v zgodbah o francoskih zakladih, a jim lahko mogoče kljub temu pripišemo določeno stopnjo zgodovinske resničnosti, povezane z izkoriščanjem vojnih razmer za ustvarjanje dobička.

Pomemben je tudi vidik materializacije folklore o Francozih. Kot je bilo rečeno, lahko povedke kot »dokaz« za resničnost svoje vsebine navajajo različne predmete, objekte, ki so ali pa niso povezani z navedenim zgodovinskim obdobjem. Lahko rečemo, da se večji

\footnotetext{
23 »Ta francoska okupacija, ki je trajala od leta 1805 do 1809 , več kot 4 leta, je zapustila tudi težke posledice krvne bolezni (LUISA), od katere so potomci degeneriki, slaboumni idioti, a po nekaterih krajih celo kreteni. Tako so pripovedovali, da je za posledico te bolezni izumrla Vakatova rodbina, Ledrarjova, Ahcova in Potokarjeva, pa tudi Francija, ki je pogorela leta 1847 s hišno št. 52 in potem tudi imela ime Francija, ni imela več potomcev.« (Zupan 1999: 69, št. 97)

${ }^{24}$ Primerjave med Turki in Francozi v folklori so pokazale več skupnih točk, hkrati pa tudi razlik. V povedkah o Turkih je veliko religijske dihotomije, v povedkah o Francozih pa seveda ne, ker je ni bilo. Odnos do Turkov je izrazito negativen, v odnosu do Francozov pa je zaznati večjo stopnjo ambivalentnosti. Folklorna podoba Turkov je, zgodovinsko gledano, v primerjavi s folkloro o Francozih manj natančna. To je po mojem mnenju povezano z večjo zgodovinsko oddaljenostjo turških vpadov, zaradi katere je lahko prazna mesta v kolektivnem spominu zasedlo več arhetipskih in generaliziranih predstav, ki Turka potisnejo v vlogo »mitičnega Drugega«, medtem ko zgodbe o Francozih v večji meri upoštevajo historično realnost.
} 
del materializirane folklore o Francozih (podobno kot pri Turkih) nanaša na predmete, objekte ali vidike fizične krajine, ki s francoskim časom nimajo ničesar opraviti in so $\mathrm{z}$ njimi povezani le v sklopu funkcije racionalizacije njihovega obstoja ali zunanje podobe.

\section{LITERATURA}

Alver, Brynjulf, 1989: Historical Legends and Historical Truth. Kvideland, Reimund, Sehmsdorf, Henning K. (ed.), Nordic Folklore: Recent Studies. Bloomington, Indianapolis: Indiana University Press, 137-149.

Anglickienè, Laima, 2004: The Image of People of Other Religions in Lithuanian Folklore. Pro Ethnologia 17, 81-93.

Belova, Olga, 2007: The Stereotype of the »Other« Within Folk Culture: An Attempt at a Formal Description. East European Jewish Affairs 37(3), 335-351.

Bizjak, Sašo, 2000: Podobe narodov in prebivalcev slovenskih dežel v Štrekljevi zbirki »Slovenske narodne pesmi in zbirki pripovedi »Glasovi«. (Neobjavljeno diplomsko delo, Univerza v Ljubljani, Filozofska fakulteta, Oddelek za etnologijo in kulturno antropologijo). Ljubljana: [samozal.].

Bokal, Milka (zbiralka), 2010: Jaz sem višje kot Marija: folklorne pripovedi iz Polhovega Gradca, Dobrove, Horjula, Šentjošta, Črnega Vrha in okoliških krajev. Celje: Celjska Mohorjeva družba, Društvo Mohorjeva družba (Zbirka Glasovi; knj. 38).

Bošković Stulli, Maja, 2002: O usmenoj tradiciji i o životu. Zagreb: Konzor.

Božović, Rade, 1977: Arapi u usmenoj narodnoj pesmi na srpskohrvatskom jezičkom području. Beograd: Filološki fakultet.

Brumen, Borut, 2000: Sv. Peter in njegovi časi. Socialni spomini, časi in identitete v istrski vasi Sv. Peter. Ljubljana: Založba /*cf.

Champion, Sara, Cooney, Gabriel, 1999: Naming the Places, Naming the Stones. Gazin-Schwartz, Amy, Holtorf, Cornelius J. (ed.), Archaeology and Folklore. London, New York: Routledge, 196-213.

Dégh, Linda, 1982: Folk Narrative. Folklore and Folklife: An Introduction. Dorson, Richard M. (ed.), Chicago: The University of Chicago Press, 53-83.

Dégh, Linda, 1996: What Is A Belief Legend? Folklore 107, 33-46.

Dégh, Linda, Vászonyi, Andrew, 1976: Legend and Belief. Ben-Amos, Dan (ed.), Folklore Genres, Austin: University of Texas Press, 93-123.

Deletić, Mirjana, Ilić Marija, 2006: Beli grad: poreklo epske formule i slovenskog toponima. Beograd: Balkanološki institut SANU.

Dolenc, Janez (zbiralec), 2000: Kres na Grebljici: povedke z Loškega pogorja. Ljubljana: Kmečki glas (Zbirka Glasovi; knj. 22).

Ferle, Mojca, 2009: Še sedaj vedo ljudje o Francozih. Žmauc, Irena, Moder, Gregor (ur.), Napoleon rezhe Iliria vstan: ob 200-letnici ustanovitve Ilirskih provinc. Ljubljana: Muzej in galerije mesta Ljubljane, Mestni muzej, 63-72.

Fortunat Černilogar, Damjana, 1993: Bovške Kluže. Ljubljana: Zavod Republike Slovenije za varstvo naravne in kulturne dediščine (Zbirka Kulturni in naravni spomeniki Slovenije: zbirka vodnikov). 
Foster, George M., 1965: Peasant Society and the Image of Limited Good. American Anthropologist 67, 293-315.

González Álvarez, David, 2008: Etnoarqueología del paisanaje tradicional como fuente de información en Arqueología. Actas de las I Jornadas de Jóvenes en Investigación Arqueológica: Dialogando con la cultura material. Madrid, 237-244.

González Álvarez, David, 2011: Arqueología, folklore y comunidades locales: los castros en el medio rural asturiano. Complutum 22(1), 133-153.

Granda, Stane, 2006: Sence Napoleonovega mita pri Slovencih. Šumrada, Janez (ur.), Napoleon na Jadranu. Koper: Univerza na Primorskem, Znanstveno-raziskovalno središče, Založba Annales: Zgodovinsko društvo za južno Primorsko, Zadar: Sveučilište, 291-303.

Granda, Stane, 2009: Vojne s Francozi v ljudskem zgodovinskem spominu. Jelenc, Janez (ur.), Ledinska kronika: zgodovinske črtice ledinske župnije. Ledine: Župnijski urad, 207-212.

Granda, Stane, 2012: Kmečki upori proti Francozom v luči Grafenauerjeve tipologije kmečkih uporov na Slovenskem. Šterbec Svetina, Barbara, Godeša, Matija (ur.), Zgodovinske dimenzije Ilirskih provinc. Ljubljana: Založba ZRC SAZU, 153-165.

Gruden, Josip, 1911: Spomini na Francoze. Zbornik Matice slovenske XIII, 1-28.

Holz, Eva, 2010: Prometne razmere. Dular, Anja, Podpečnik, Jože, Šumrada, Janez (ur.), Pod Napoleonovim orlom: 200 let ustanovitve Ilirskih provinc: razstavni katalog. Ljubljana: Narodni muzej Slovenije, 96-101.

Hrobat, Katja, 2007: Use of Oral Tradition in Archaeology: the Case of Ajdovščina Above Rodik, Slovenia. European Journal of Archaeology 10(1), 31-56.

Hrobat, Katja, 2010: Ko Baba dvigne krilo. Prostor in čas v folklori Krasa. Ljubljana: Znanstvena založba Filozofske fakultete.

Humar, Gorazd, 2012: Kratek sprehod skozi zgodovino gradnje mostov na ozemlju današnje Slovenije: od davnine do začetka 2. svetovne vojne. Arhitektov bilten: AB: mednarodna revija za teorijo arhitekture 42(195/196), 54-57.

Klintberg, Bengt af., 1989: Legends Today. Kvideland, Reimund, Sehmsdorf, Henning K. (ed.), Nordic Folklore. Recent Studies. Bloomington; Indianapolis: Indiana University Press, 70-89.

Kolar, Nataša, 2012: Francoska zasedba slovenske Štajerske leta 1809 na ptujsko-ormoškem območju. Šterbec Svetina, Barbara, Godeša, Matija (ur.), Zgodovinske dimenzije Ilirskih provinc. Ljubljana: Založba ZRC SAZU, 39-56.

Kotnik, Francè (zbral in uredil), 1957: Storije. Koroške narodne pripovedke in pravljice. Celovec: Družba sv. Mohorja.

Krekovičová, Eva, 1997: Jewishness in the Eyes of Others: Reflection of the Jew in Slovak Folklore. Human Affairs 7(2), 167-183.

Kropej, Monika, 2008: Od ajda do zlatoroga: slovenska bajeslovna bitja. Celovec, Ljubljana, Dunaj: Mohorjeva.

Kuhar, Boris, 1964: Francozi v slovenskem ljudskem izročilu. Reisp, Branko, Zelinkova, Darinka (ur.), Napoleonove Ilirske province: 1809-1814: razstava v Narodnem muzeju v Ljubljani. Ljubljana: Narodni muzej, 99-116.

Kuljić, Todor, 2012: Kultura spominjanja: teoretske razlage uporabe preteklosti. Ljubljana: Znanstvena založba Filozofske fakultete.

Kumer, Zmaga, 1957: Francozi v Ljubljani. Slovenska glasbena revija IV(2-3), 17-21.

Kure, Bogomira (zbiralka), 2004: Zgodbe ne moreš iz žakla zvrnit: folklorne pripovedi iz Bele krajine. Ljubljana: Kmečki glas (Zbirka Glasovi; knj. 28). 
Kvartič, Ambrož, 2014: Sodobne povedke (neobjavljena doktorska disertacija, Univerza v Ljubljani, Filozofska fakulteta). Ljubljana: [samozal.].

Kvideland, Reimund, Sehmsdorf, Henning K., (ed.), 1988: Scandinavian Folk Belief and Legend. Minneapolis: University of Minnesota Press.

Layton, Robert, 1999: Folklore and World View. Gazin-Schwartz, Amy, Holtorf, Cornelius J. (ed.), Archaeology and Folklore. London, New York: Routledge, 26-34.

Leerssen, Joep, 2007b: Ethnocentrism, Eurocentrism. Beller, Manfred, Leerssen, Joep (ed.), Imagology: The Cultural Construction and Literary Representation of National Characters: A Critical Survey. Amsterdam, New York: Rodopi (Studia imagologica; 13), 323-324.

Lindow, John, 1995: Supernatural Others and Ethnic Others: A Millenium of World View. Scandinavian Studies 67(1), 8-31.

Makarovič, Marija, 1955: Kmet ziblje Francoza. Slovenski etnograf 8, 153-169.

Del Mar Llinares, María, 1990: Mouros, ánimas, demonios. El imaginario popular gallego. Madrid: Akal.

Matteoni, Francesca, 2008: The Jew, the Blood and the Body in Late Medieval and Early Modern Europe. Folklore 119, 182-200.

Mencej, Mirjam, 2006: Coprnice so me nosile. Raziskava vaškega čarovništva v vzhodni Sloveniji na prelomu tisočletja. Ljubljana: Filozofska fakulteta, Oddelek za etnologijo in kulturno antropologijo (Zbirka Županičeva knjižnica; št. 18).

Mlakar, Anja, 2016: Drugi v slovenski folklori (neobjavljena doktorska disertacija, Univerza v Ljubljani, Filozofska fakulteta). Ljubljana: [samozal.].

Morato, Nada (zbiralka), 2002: Mrak eno jutrnja: štorije iz Slovenske Istre. Ljubljana: Kmečki glas (Zbirka Glasovi; knj. 25).

Nora, Pierre, 1989: Between Memory and History. Representations 26, 7-25.

Orožen, Janko, 1936: Gradovi in graščine v narodnem izročilu. 1, Gradovi in graščine ob Savinji, Sotli in Savi. Celje: [samozal.].

Ožbolt, Milena (zbiralka), 2004: Andrejeva stopinja: folklorne pripovedi iz Loške doline, Blok, Loškega potoka in okolice Cerkniškega ter Babnega Polja. Ljubljana: Kmečki glas (Zbirka Glasovi; knj. 29).

Parafita, Alexandre, 2006: A Mitologia dos Mouros. Lendas, Mitos, Serpentes, Tesouros. Amadora: Edições Gailivro.

De Pina Cabral, João, 1989: The Valuation of Time Among the Peasant Population of the Alto Minho, Northwestern Portugal. Layton, Robert (ed.), Who Needs the Past: Indigenous Values and Archaeology. London, New York: Routledge (One World Archaeology; 5), 59-69.

Polajnar, Janez, 2009: Ilirske province, Francozi in mit narodne osvoboditve. Žmauc, Irena, Moder, Gregor (ur.), Napoleon rezhe Iliria vstan: ob 200-letnici ustanovitve Ilirskih provinc. Ljubljana: Muzej in galerije mesta Ljubljane, Mestni muzej, 27-41.

Primc, Jože (zbiralec), 1997: Okamneli mož in druge zgodbe iz Zgornje Kolpske doline: (od Babnega Polja in Prezida, preko Gerova, Čabra, Osilnice, Kužlja, Kostela, Fare do Dola in Predgrada). Ljubljana: Kmečki glas (Zbirka Glasovi; knj. 15).

Pugelj, Sabina (zbiralka), 2012: Vile bile: dolina Reke od Ilirske Bistrice do Zabič in Hrušice. Celje: Celjska Mohorjeva družba, Društvo Mohorjeva družba (Zbirka Glasovi; knj. 41).

Radešček, Rado, 1983: Slovenske legende. Ljubljana: Cankarjeva založba.

Ravbar Molato, Nada (zbiralka), 2007: Kruh in ribe: od Bržanije prek Trsta do Soče. Celje: Celjska Mohorjeva družba, Društvo Mohorjeva družba (Zbirka Glasovi; knj. 32). 
Reboredo, J. M. González, 1983: Lendas galegas de tradición oral. Vigo: Galaxia.

Rozhodestvenskiy, Metodiy, 2013: Claiming What Belongs to the Others: On Barbarian Rhetoric in Late Antiquity and the Early Middle Ages. CAS Working Paper Series (Issue 5), 3-47.

Rutar, Simon, 1882: Zgodovina Tolminskega: zgodovinski dogodki sodnijskih okrajev Tolmin, Bovec in Cerkno ž njih prirodoznanskim in statističnim opisom. Gorica: Josip Devetak.

Samec, Marija (zbiralka), 2014: So z vilicami pisali: folklorne pripovedi iz občine Grosuplje in okolice. Ljubljana: Založba ZRC, ZRC SAZU (Zbirka Glasovi; knj. 44).

Slapšak, Božidar, 1995: Možnosti študija poselitve v arheologiji. Ljubljana: Filozofska fakulteta (Arheo: arheološka obvestila; 17).

Stanonik, Marija, 1999: Slovenska slovstvena folklora. Ljubljana: DZS.

Stanonik, Marija (zbiralka), 2001: Bela Ljubljana: zgodbe iz slovenske prestolnice. Ljubljana: Kmečki glas (Zbirka Glasovi; knj. 23).

Stanonik, Marija, 2008: Interdisciplinarnost slovstvene folklore. Ljubljana: Založba ZRC SAZU.

Stele, France (zapisal), 2013: Zlati hrib: pravljice in povedke iz Tunjic in okolice. Kamnik: Matična knjižnica.

Šmitek, Zmago, 1986: Klic daljnih svetov: Slovenci in neevropske kulture. Ljubljana: Založba Borec.

Šmitek, Zmago, 2001: Mitološki in pravljični čas. Traditiones 30(2), 7-25.

Šmitek, Zmago, 2003: Sledovi potujočih duš. Vedomci, kresniki in sorodna bajna bitja. Radovljica: Didakta.

Šmitek, Zmago, 2005: Moč ti je dana. Slovenske pripovedi o junakih in zgodovinskih osebnostih. Radovljica: Didakta.

Šmitek, Zmago, 2009: Kralj Matjaž: mavrični sij ljudskega junaka. Acta historiae 17(1-2), 127-140.

Štrekelj, Karol, 1895-1923: Slovenske ljudske pesmi. Ljubljana: Slovenska matica.

Šumrada, Janez, 2010: Napoleonova Ilirija in Slovenci. Dular, Anja, Podpečnik, Jože, Šumrada, Janez (ur.), Pod Napoleonovim orlom: 200 let ustanovitve Ilirskih provinc: razstavni katalog. Ljubljana: Narodni muzej Slovenije, 24-49.

Tangherlini, Timothy R., 1988: Ships, Fogs, and Traveling Pairs: Plague Legend Migration in Scandinavia. The Journal of American Folklore 101(400), 176-206.

Tangherlini, Timothy R., 1990: »It Happened Not Too Far from Here...«: A Survey of Legend Theory and Characterization. Western Folklore 49(4), 371-390.

Tangherlini, Timothy R., 1995: From Trolls to Turks: Continuity and Change in Danish Legend Tradition. Scandinavian Studies 67(1), 32-62.

Tončič Štrancar, Marija (zbiralka), 2005: Frk čez drn-frk čez trn: prolke, pravce, štorce in prfjetce iz Brkinov in Čičarije. Ljubljana: Kmečki glas (Zbirka Glasovi; knj. 30).

Valenčič, Vlado, 1970: Sadjarstvo. Gospodarska in družbena zgodovina Slovencev. Zgodovina agrarnih panog. Zv. 1, Agrarno gospodarstvo. Ljubljana: Državna založba Slovenije, 317-341.

Verdinek, Bojana (zbiralka), 2002: Lesene cokle: folklorne pripovedi iz Mežiške, Mislinjske in Šaleške doline. Ljubljana: Kmečki glas (Zbirka Glasovi; knj. 26).

Vidic, Marko (ur.), 2001: Ilustrirana zgodovina Slovencev. Ljubljana: Mladinska knjiga.

Vinogradova, Lyudmila N., 1999: Notions of »Good« and »Bad« Death in the System of Slavic Beliefs. Etnolog 9(1), 45-49.

Vodopivec, Peter, 2006: Od Pohlinove slovnice do samostojne države: slovenska zgodovina od konca 18. stoletja do konca 20. stoletja. Ljubljana: Modrijan.

Zupan, Marjan (zbiralec), 1999: Rpečnekova vučca: folklorne pripovedi z visoke Gorenjske (in iz Kanalske doline). Ljubljana: Kmečki glas (Zbirka Glasovi; knj. 20). 


\section{“THE FRENCH CAME AND BROUGHT 'A DIFFERENT TIME”": NAPOLEON'S FRENCH FORCES IN SLOVENE LEGENDS IN THE CONTEXT OF THE COLLECTIVE MEMORY AND OTHERNESS ANJa MLaKar $\infty$}

Folklore often looks to the past, especially to events and eras that have a special significance for its bearers. In this sense, we can see folklore as a part of collective memory that has a major role in the construction of collective identities. Folklore depicts historical invaders as "the Others" and narrates stories about them in accordance with the needs of the community and is as such often incompatible with historical reality. Napoleon's French forces that invaded and conquered the territory of what is today Slovenia in the late $18^{\text {th }}$ and early $19^{\text {th }}$ centuries had a significant effect on Slovene folklore. Legends depict violent confrontations between the French soldiers and the population under siege and the ways the French exploited the population; generally, the attitude towards the French in legends is negative. At the same time, there are some legends that display a more amicable relationship or even humorous occurrences (mostly based on the French not understanding the Slovene language). In these legends that depict life in war times and under the French rule, we can recognize some correspondence with the historical reality of that era as preserved in the collective memory. Although some segments of the French rule are completely ignored by legends - this perhaps is because the French presence in these territories was short and all the changes they intended to install were not fully integrated into society. Yet in other cases, the narratives about the French move away from the historical and express beliefs about the supernatural and the world beyond. These legends express a connection with the time of the French because this era clearly holds certain significance for the bearers of this folklore. In some legends, the "French times" are utilized to explain certain aspects of the physical landscape. Connecting "the Other" to specific spots in the landscape is common in folklore, although the historical link is false, questionable or remains to be studied. Another historical inconsistency in these legends can be seen in a part of folklore in which we observe an interchangeability of different characters, or better said, of different historical invaders - for example legends that do not distinguish to a great degree between the "French time" and the "Turkish time". This expresses the tendency of folklore to adjust its content (or its characters) to what best suit the needs of its bearers and expresses their worldview even if this means being incoherent with historical reality.

Dr. Anja Mlakar, Muzej novejše zgodovine Slovenije, Celovška c. 23, SI-1000 Ljubljana, Slovenija, anja.mla@gmail.com 